INTERNATIONAL MONETARY FUND
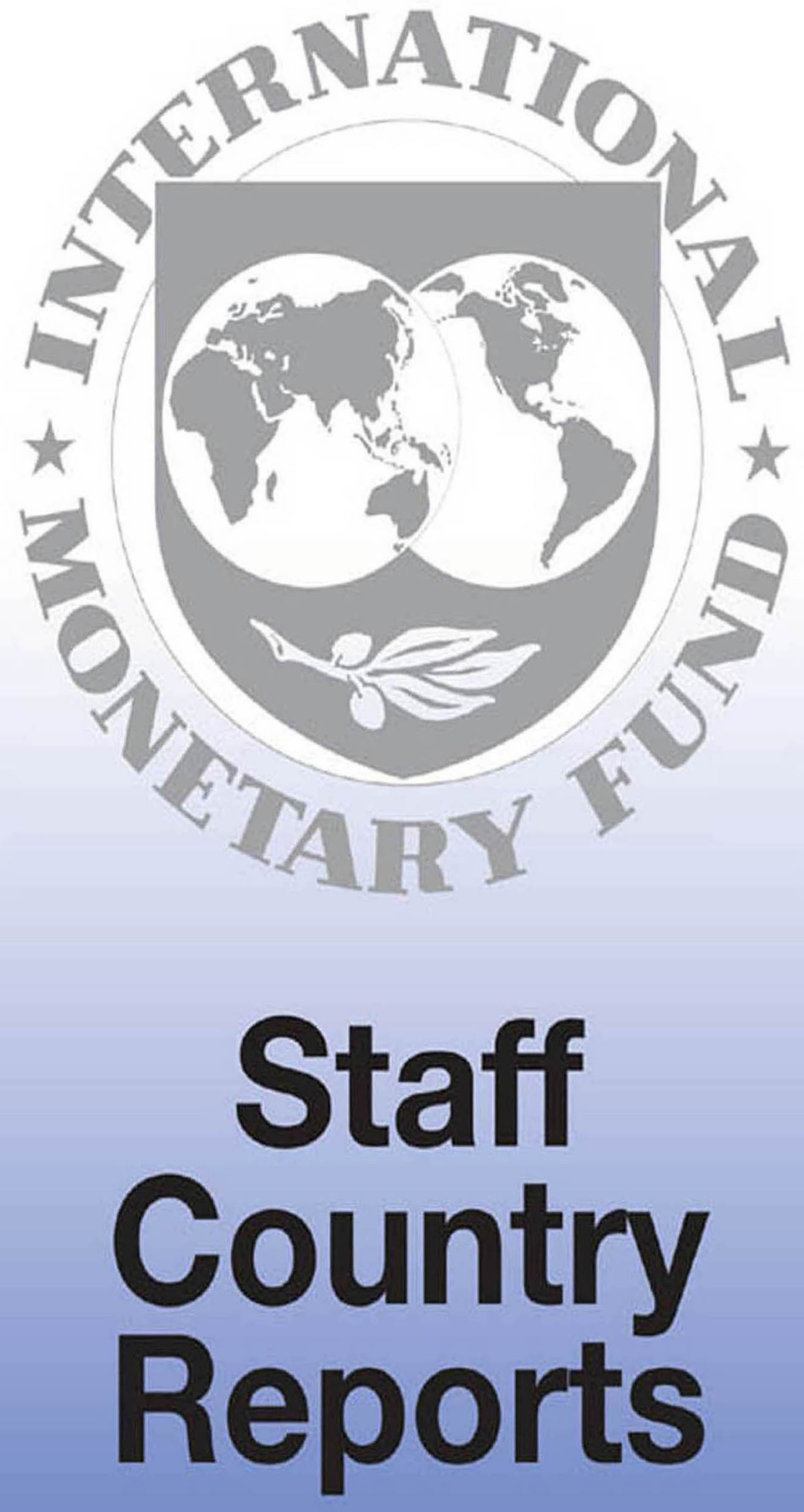


\section{Japan: Financial Sector Assessment Program-Technical Note on Credit Intermediation}

This paper was prepared based on the information available at the time it was completed in August 2012. The views expressed in this document are those of the staff team and do not necessarily reflect the views of the government of Japan or the Executive Board of the IMF.

The policy of publication of staff reports and other documents by the IMF allows for the deletion of market-sensitive information.

Copies of this report are available to the public from

International Monetary Fund • Publication Services

$70019^{\text {th }}$ Street, N.W. • Washington, D.C. 20431

Telephone: (202) 623-7430 • Telefax: (202) 623-7201

E-mail: publications@imf.org Internet: http://www.imf.org

\section{International Monetary Fund Washington, D.C.}


FInANCIAL SECTOR ASSESSMENT PROGRAM

\section{JAPAN}

CREDIT INTERMEDIATION

TECHNICAL NOTE

August 2012

INTERNATIONAL MONETARY FUND

MONETARY AND CAPITAL MARKETS DEPARTMENT 


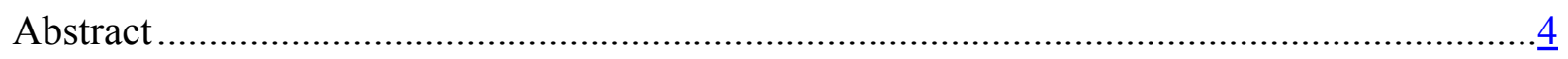

I. Credit Conditions: Background and Recent Trends ...........................................................

II. Credit Intermediation: Impact of Low Interest Rate Environment …………………..........

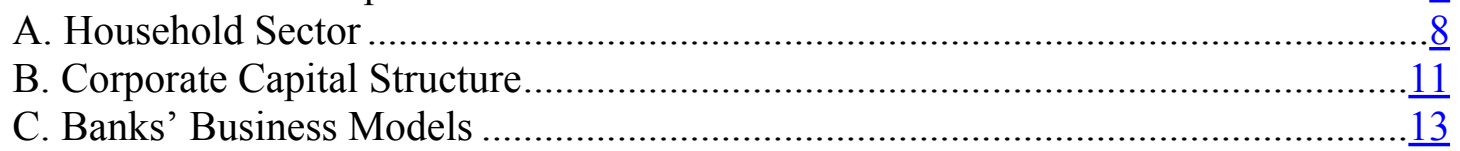

III. Credit Intermediation: Potential Bottlenecks ................................................................

A. Government's Role in the Financial System...................................................

B. Structural Weakness of SMEs..........................................................................

C. Market Practices on Collaterals and Risk-Based Financing ……………………...27

D. Financial Position of Regional and Shinkin Banks..............................................

E. Institutional and Regulatory Factors ...............................................................

IV. Improving Efficiency of Credit Channels....................................................................

Tables

1. Government Support Programs to Facilitate SMEs Financing, 2008-2011 .........................17

2. Comparison of Selected Government-Affiliated Financial Institutions (GFIs)....................23

3. Summary Statistics of the Corporate Sector-By Industry and Capital Size .........................25

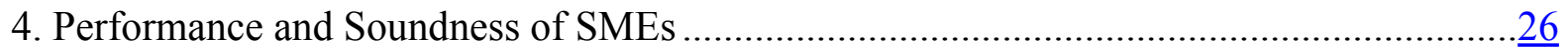

5. Regression Estimates on Corporate Adjusted Net Profit ..................................................

6. Estimated Share of Credit Guarantees for SMEs, by bank types ........................................

Figures

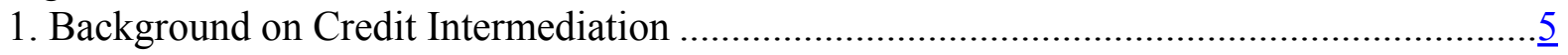

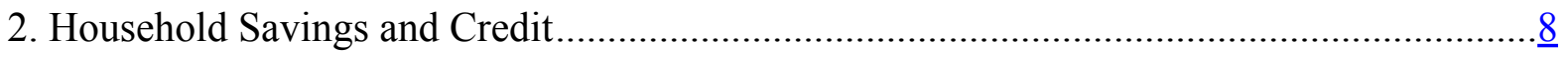

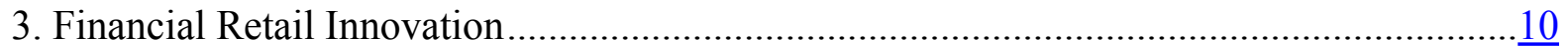

4. Corporate Capital Structure under Low Interest Rates ....................................................11

5. Shifts of Banks' Business Models under Low Interest Rates ............................................13

6. Government Credit Support to the Financial System ……….....................................16

7. Benefits and Costs of Government Support Measures …………...................................18

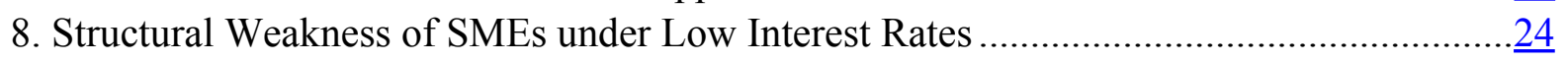

9. Market Practices and Institutional Features of Credit Intermediation ..................................28

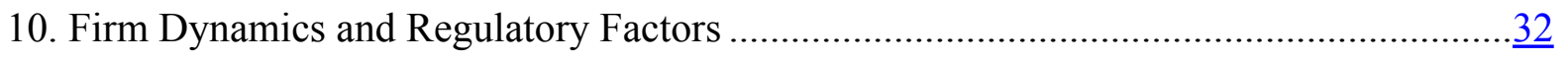




\section{Appendices}

I. Regression Analysis on Household Portfolio Allocation Across Age and Cohorts.

II. Key Credit Support Measures in Response to the Financial Crisis and the Earthquake......

III. Reforms of Japan Post Bank and Insurance and Other GFIs .........................................43

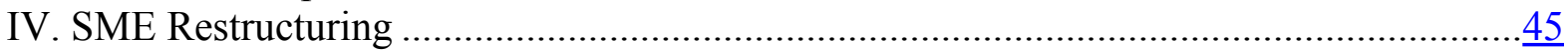

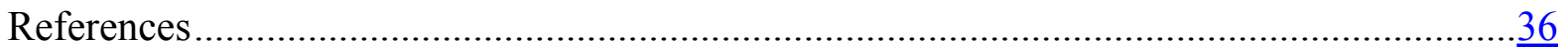




\begin{abstract}
$\operatorname{ABSTRACT}^{1}$
The overall credit conditions in Japan have eased but credit demand remains inert. Swift policy actions helped prevent a tightening of financing condition and widespread bankruptcies. However, several aspects in the financial system could impede the wellfunctioning of the credit channel. These include: (i) selected public credit support measures and expanding role of government-affiliated financial institutions; (ii) structural weakness of small- to medium-sized enterprises (SMEs); (iii) risk-averse market practices on collaterals and risk-based financing; (iv) financial positions of regional and shinkin banks; and (iv) some institutional and regulatory factors. Financial sector policies should aim to improve credit intermediation and revive credit demand by a better-target credit support program, advancing reforms in government-affiliated financial institutions (GFIs) and SME restructuring, encouraging electronic registration on claims, promoting risk-based financing, and strengthening regional and shinkin banks risk management.
\end{abstract}

\footnotetext{
${ }^{1}$ The authors of this note are Mr. W. Raphael Lam (APD) and Mr. Jongsoon Shin (OAP), who are part of the FSAP team. The analysis has benefitted from discussions with staff from Bank of Japan (BoJ), Japan Financial Services Agency (FSA), Ministry of Economy, Trade, and Industry (METI), Professor Tagashira, Mr. Takagi (bankruptcy lawyer), research scholars led by Mr. Ono at Mizuho Research Institute, and Messrs. Tsukada and Takahashi of the Credit Risk Database (CRD), Japan Venture Capital Association, and credit managers and loan officers of selected major banks, regional banks, and credit cooperatives.
} 


\section{Credit Conditions: BACKground And Recent Trends}

\section{In Japan, private sector credit is mostly channeled through the banking system.} Debt financing accounts for nearly 60 percent of corporate finance, with most credit channeled through the banking system (about $¥ 238$ trillion or 50 percent of GDP) (Figure 1). Large corporations, in addition to bank finance, have direct access to capital markets such as corporate bonds and commercial papers, of which the outstanding amount is about $¥ 60$ trillion and $¥ 10$ trillion, respectively. Though major banks mostly finance large corporations in Japan and overseas, they also lend substantially to SMEs. Regional banks and credit cooperatives tend to specialize on SME lending in their own regions. All banks are active in housing loans and consumer credit.

\section{Figure 1. Japan: Background on Credit Intermediation}

Corporate credit has declined over the years but remains channeling through the banking system...

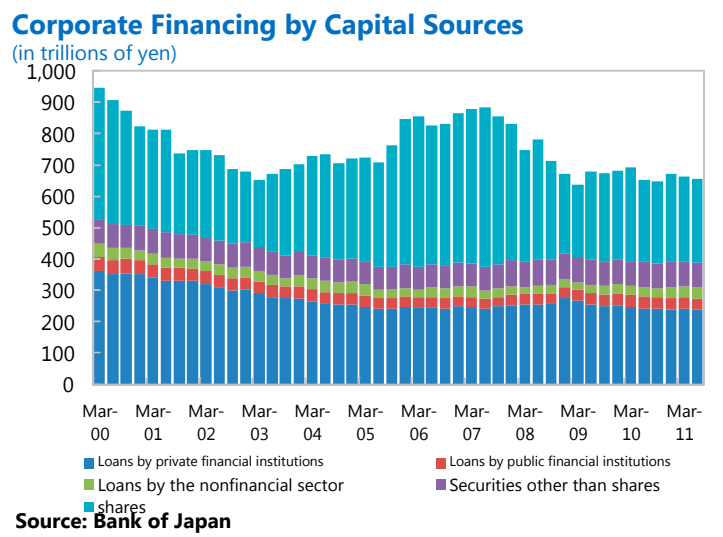

Lending attitudes continue to improve, even for SMEs that often face structurally financial constraint...

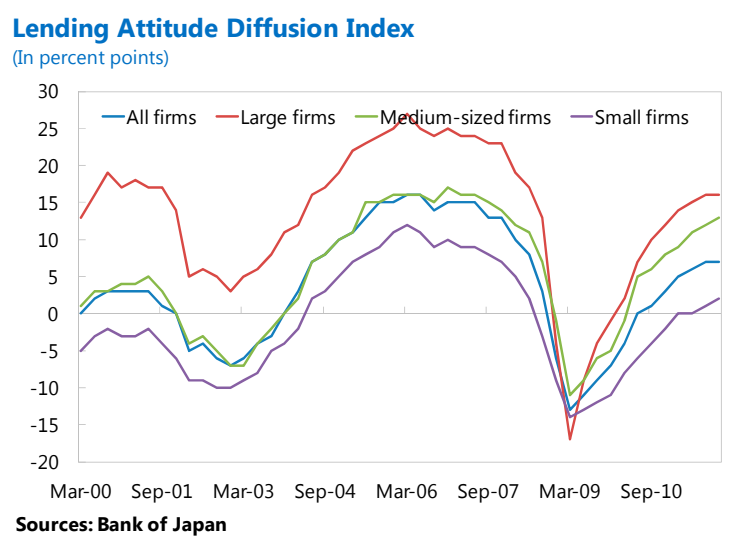

... and most of bank credits are extended to SMEs.

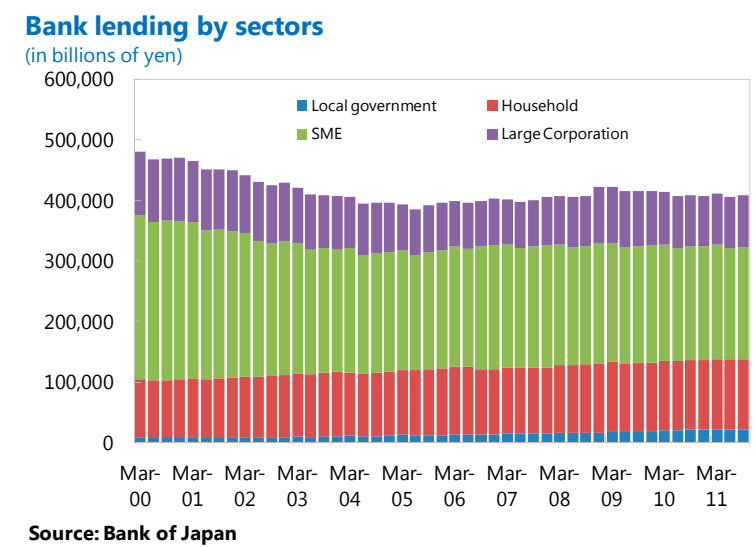

... but credit demand remains subdued.

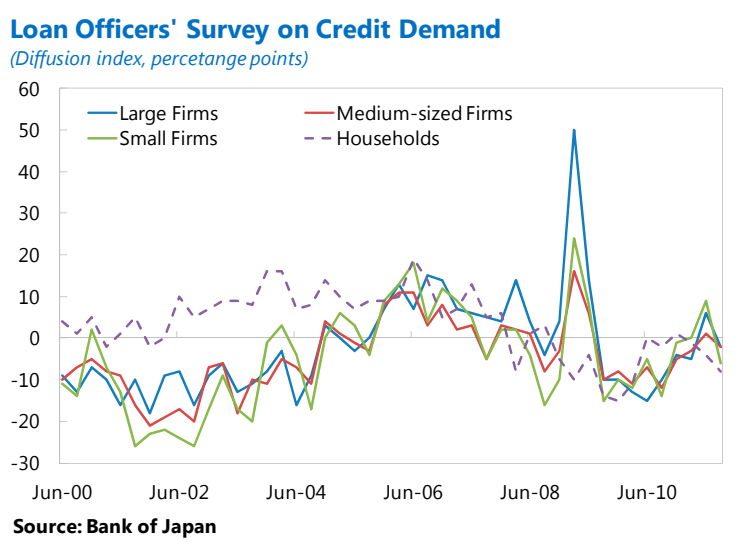


Figure 1. Japan: Background on Credit Intermediation (cont'd)

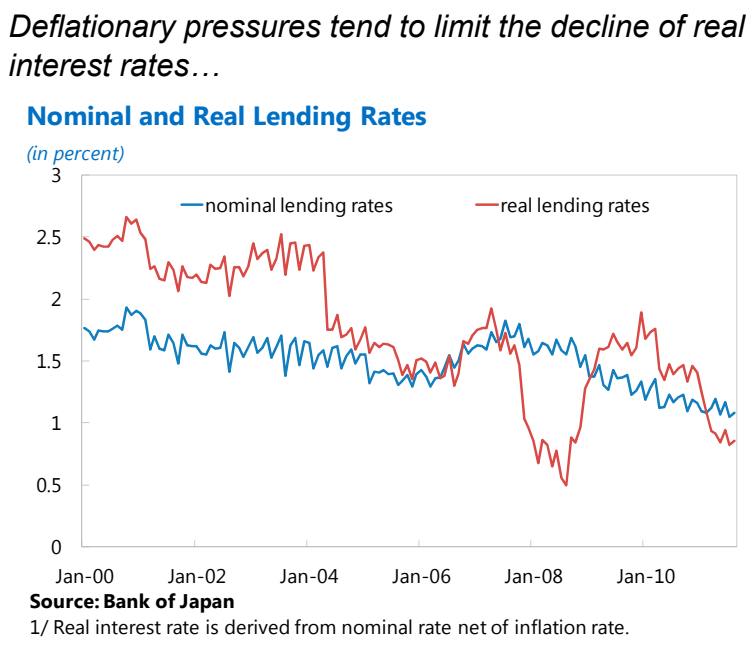

Despite deleveraging, bank credit to the private sector remains relatively high among $G 7$ countries.

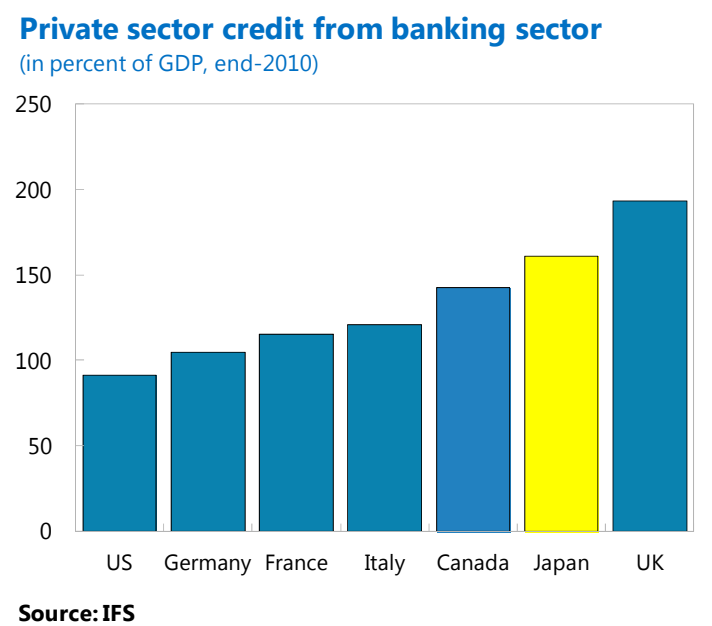

2. GFIs have played a key role in facilitating credit. ${ }^{2}$ While these GFIs have a declining presence in the financial system over the past decade (shrinking from 21 percent to 11 percent of total assets in the financial system as of end-FY2010, excluding Japan Post Bank (JPB) and Insurance (JPI)), they are still active in the credit intermediation by implementing policy directives and facilitating credits to firms that face financial constraints. In addition, JPB and JPI, the largest bank and life insurance company by deposits and policy premium, channel considerable amount of private savings to investment securities (of which over 80 percent are Japanese government bonds (JGBs)), although these two institutions do not extend credit.

\section{Overall financial conditions of firms and households have continued to ease} amid the low interest rate environment. ${ }^{3}$ Accommodative lending attitudes have also contributed to a downward trend for private sector funding costs to about 1 percent, driven by a decline of funding costs amid the monetary easing and intensifying competition. Except during the peak of Lehman crisis and immediately after the Great East Japan Earthquake,

\footnotetext{
${ }^{2}$ In this note, GFIs refer to financial institutions that are publicly-held and those private financial institutions that remain affiliated with the government through indirect ownership, supervision, and credit policy. In this note, GFIs include Japan Housing Finance Agency (JHF), Japan Finance Corporation (JFC), Development Bank of Japan (DBJ), Shoko-Chukin bank (SCB), Fiscal Investment Loan Program (FILP) and for the purpose of discussing reform agenda, we also include JPB and JPI.

${ }^{3}$ A well-functioning credit intermediation involves a smooth transfer of credits from savers to borrowers, characterized by the ease at which borrowers can obtain access to funding and lenders to provide funds with a sound capacity. Credit demand and supply are responsive to interest rates and other price signals. Overall, the financial system channels funds through a diverse set of financing means to most productive uses.
} 
overall financing conditions have continued to ease but some SMEs and households have somewhat faced financial constraints (Figure 1). Specifically:

- Banks' lending attitudes for corporations continue to improve to near pre-crisis levels, even for SMEs that often face structurally financial constraints. Easing financing condition is also made possible by banks' steady deposit inflow and strengthened capital, where the capital adequacy ratio is high at about 14 percent.

- Funding conditions in debt market have been favorable, as corporate bond spreads returned to pre-crisis level (e.g., less than $1 \frac{1}{2}$ percent for AA-rated) and bond issuances gradually resumed, though issuance for utility companies (about one-quarter of the outstanding corporate bonds) was temporarily affected after the disaster. Equity market, however, remains subdued. Securitization market, beginning to develop in the mid-2000s, has yet recovered to pre-crisis levels (see section II.B). Availability of risk-based capital, such as private equity and venture capital, remains very limited.

- Consumer finance other than mortgages has somewhat tightened following prudential regulations related to consumer protection (Amended Money Business Law, June 2010), which affect mostly on consumer finance companies. The nonperforming loan ratios for the consumer finance companies have increased, but are not expected to affect the overall credit conditions significantly given strong household balance sheets, the relatively small size and strong ties with major banks of these consumer finance companies.

\section{Despite relatively easy financing} conditions, credit demand has remained weak. Loan-to-deposit ratio is at historical low at less than 70 percent (text chart). Diffusion index on credit demand remains negative in the Tankan survey. Weak growth prospects, strong yen, and high corporate surpluses have deterred corporations from taking credit, where capital expenditures for business fixed investment only account for less than 30 percent of total credit demand. Structural factors - such as high leverage among SMEs, demographic change, and shrinking regional economy - have further contributed to weak credit demand. Nevertheless, bank lending has somewhat picked up recently, reflecting reconstruction demand, pickup in housing loans, and banks' overseas expansion (Figure 1).

\section{CREDIT INTERMEdiATION: IMPACT OF LOW INTEREST RATE ENVIRONMENT}

\section{Credit intermediation in Japan has been affected by the low nominal interest} rate environment. The low interest rate environment has persisted for nearly a decade, and is likely to remain over the medium term (IMF, 2012). Lingering deflation, however, tends to limit the decline of real interest rate to sufficiently stimulate credit demand. This section 
examines several areas how low interest rates have affected various segments of credit intermediation.

\section{A. Household Sector}

\section{Interest rate channels of household credit intermediation appear to be}

functioning. In particular, households have adjusted to low interest rates in a few dimensions (Figure 2):

\section{Figure 2. Japan: Household Savings and Credit}

Household financial assets are over 5 times of disposable income, the highest among $\mathrm{G} 7$ countries...

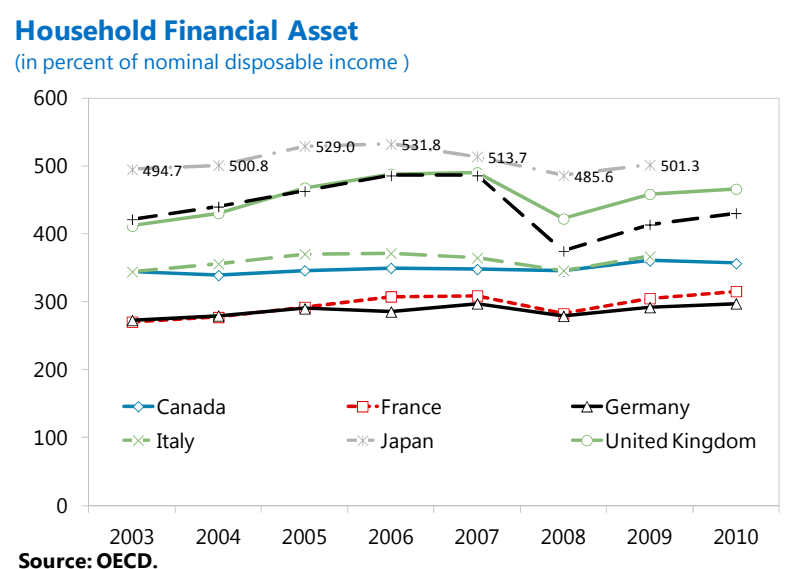

.. which are the highest among G7.

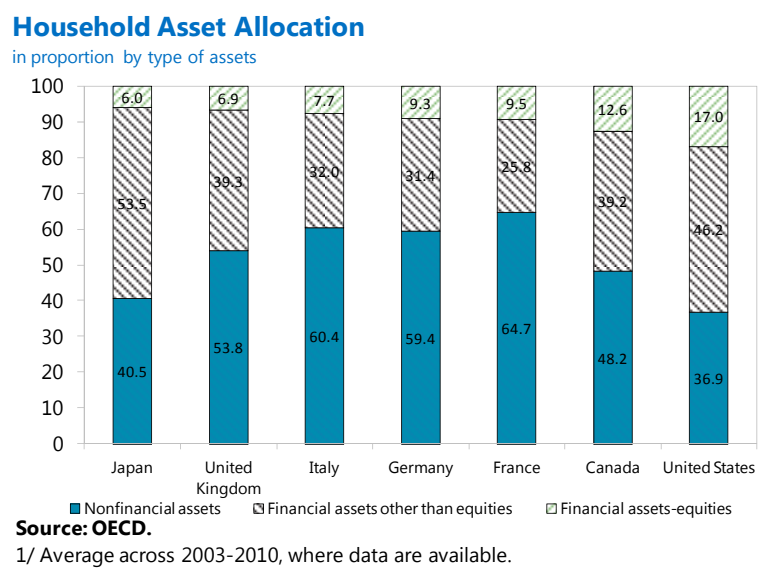

... and the financial assets are largely held in cash and deposits,

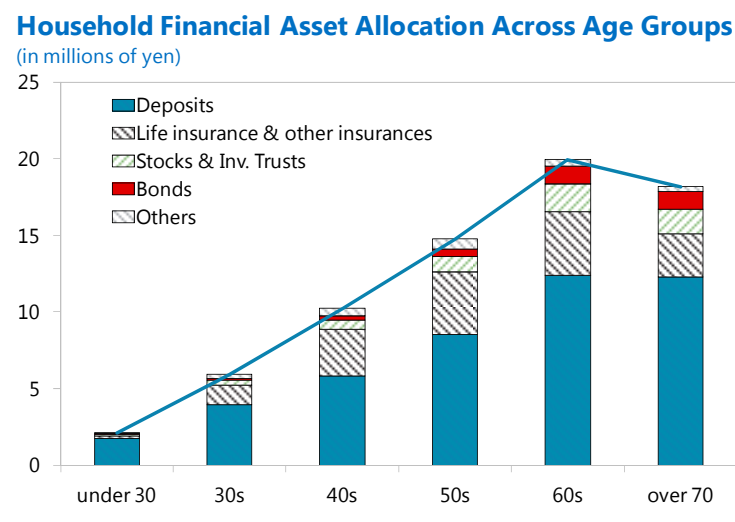

Source: National Survey of Family Income and Expenditure-2009 and Hasegawa and Lam (2011).

House price to income ratio has continued to decline and is comparably affordable relative to other advanced countries.

Housing Affordability: Proprety Price to Income Ratio

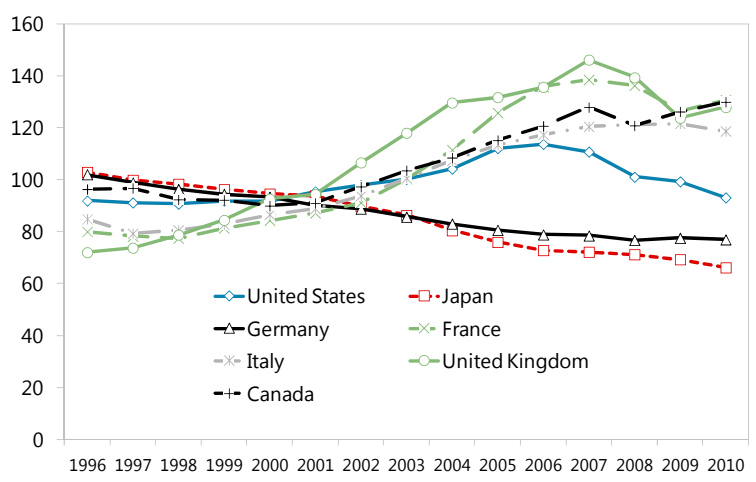
Source: OECD. 
Figure 2. Japan: Household Savings and Credit (cont'd)

Following reforms in JFHA, banks have expanded in mortgage loans, providing most of total mortgages...

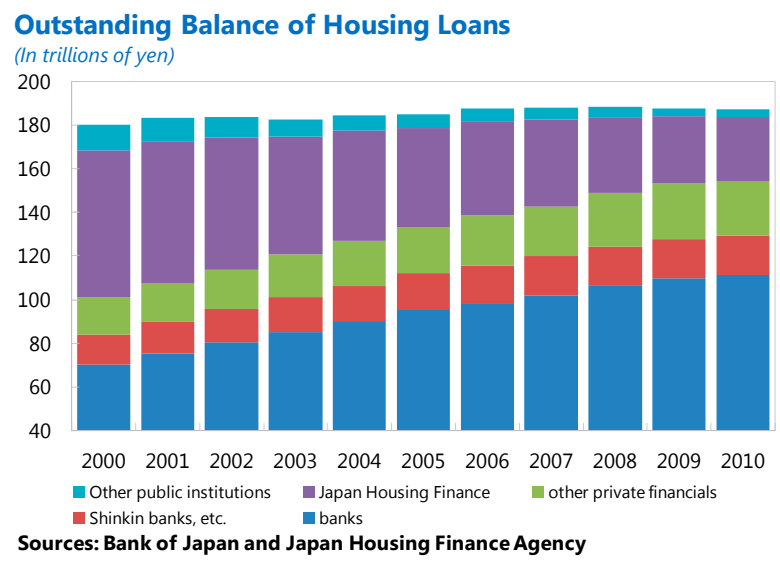

... and households also shifted towards flexible-rate mortgages partly under low interest rates.

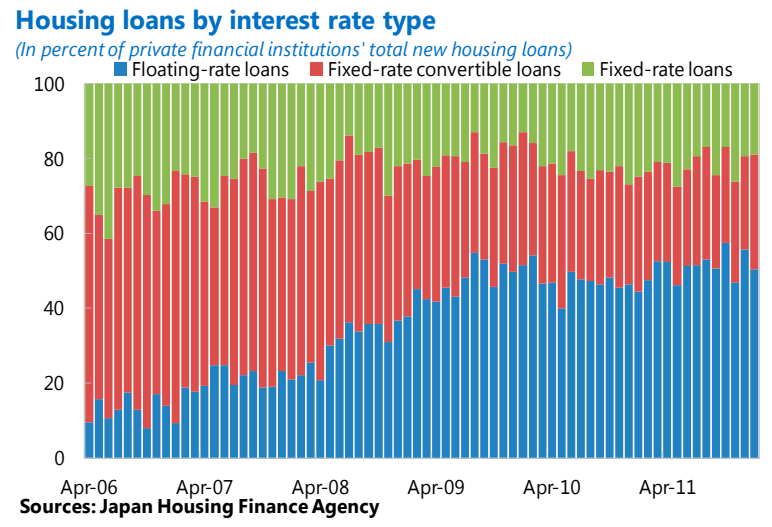

- Households respond to asset returns in their financial asset allocation. Household financial assets (nearly $¥ 1,500$ trillion as of 2010) are over five times of their nominal disposable income, highest among G7 countries, and are mostly held in cash and deposits. Abundant net asset gives some flexibility on portfolio allocation despite low risk appetite in general. Estimates using household survey data (Hasegawa and Lam, 2011) suggest that financial asset allocation is responsive to asset returns, after controlling for age and cohort differences. For instance, a one-percentage point increase of real interest rate would increase deposit to financial asset ratio by two percentage points for the elderly between 60 and 70 who were born during 1940-44 (Appendix A).

\section{- Households have gradually shifted savings to seek higher returns. While} maintaining most financial assets in deposits, household savings have increasingly been channeled through new retail financial products in pursuant of higher returns (FSAP Capital Market note and Figure 3). Retail financial innovations such as investment trusts (toushin funds), J-REITs, ETFs/ETNs, and retail foreign exchange (FX) margin trading activities were introduced to meet such demand. Activities in these products have sustained during the global financial crisis. 


\section{Figure 3. Japan: Financial Retail Innovation}

More retail financial products, such as ETF/ETN, are available for retail investment,

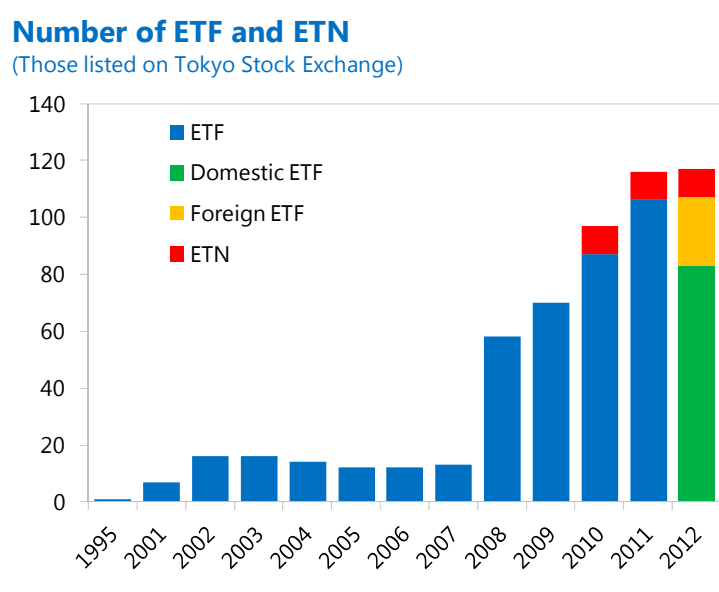

Sources: Tokyo Stock Exchange

Activities of retail investment through financial innovation have been stable after the Lehman crisis ...

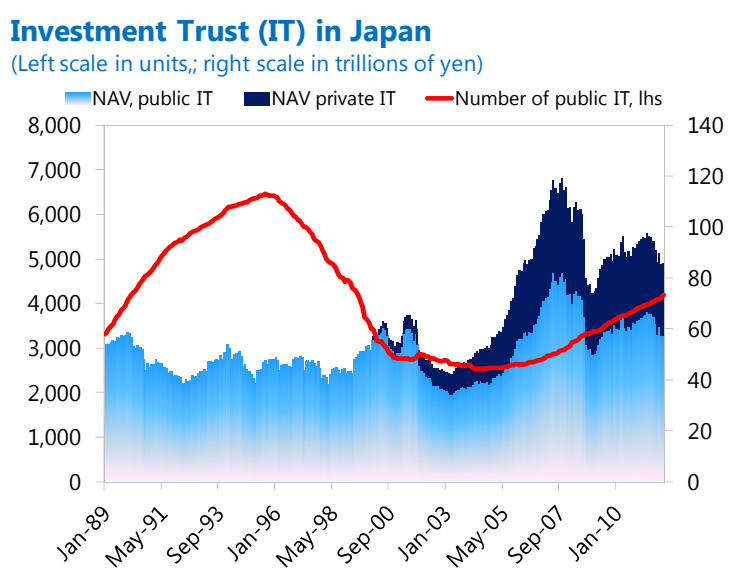

Sources: CEIC, The Investment Trusts Association, Japan

... and retail $f x$ trading gradually expanding,

Retail FX margin trading, Open Interest at Tokyo

Financial Exchange ( 3 month moving average)

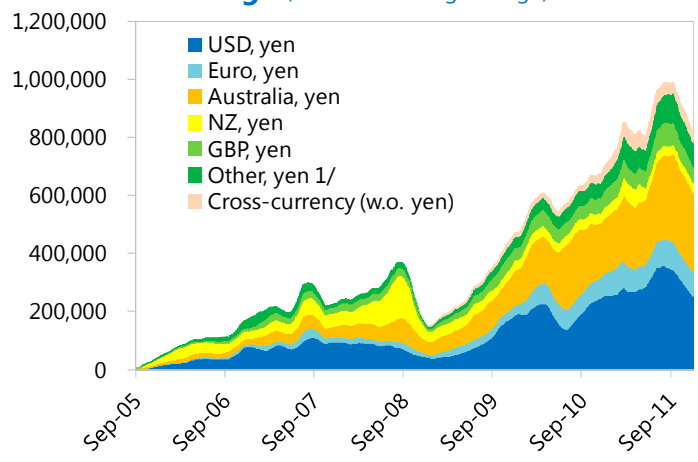

Sources: Tokyo Financial Exchange

1/ Including currencies from Switzerland, Canda, South Africa, Norway, Sweden, Hong Kong, Poland, China, South Korea, and India.
... which are mainly equity-based.

ETF by type of underlying assets

(Number of funds and their share in total, as of January 2012)

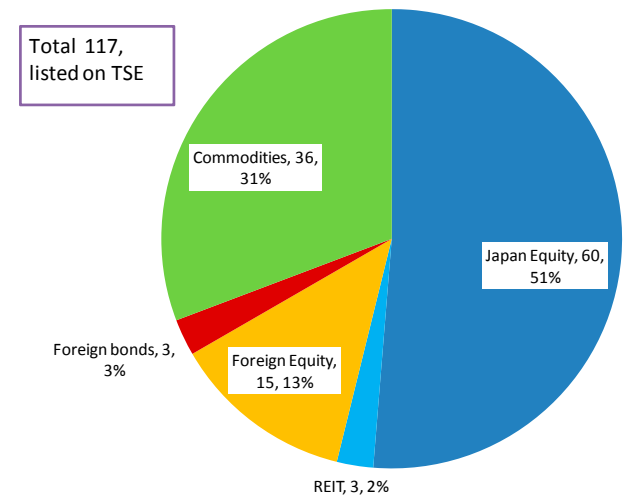

Sources: Tokyo Stock Exchange

... with publicly offered investment trust ...

Publicly Offered Investment Trust in Japan: 2001-2011

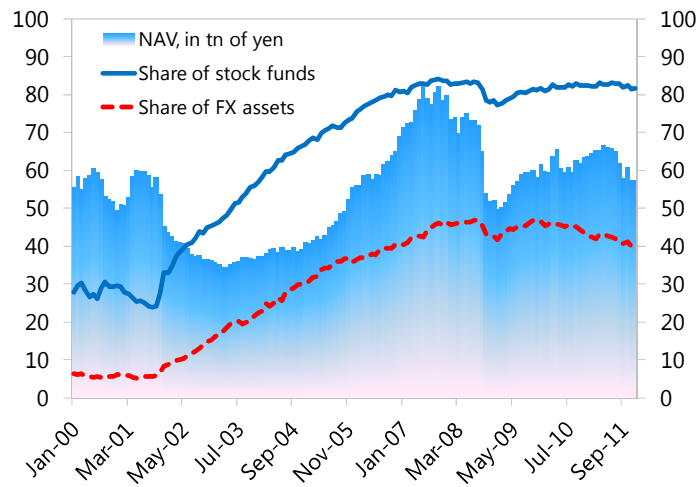

Sources: CEIC

..., along with the REIT market.

Development of J-REIT Market

(In trillions of yen, number)

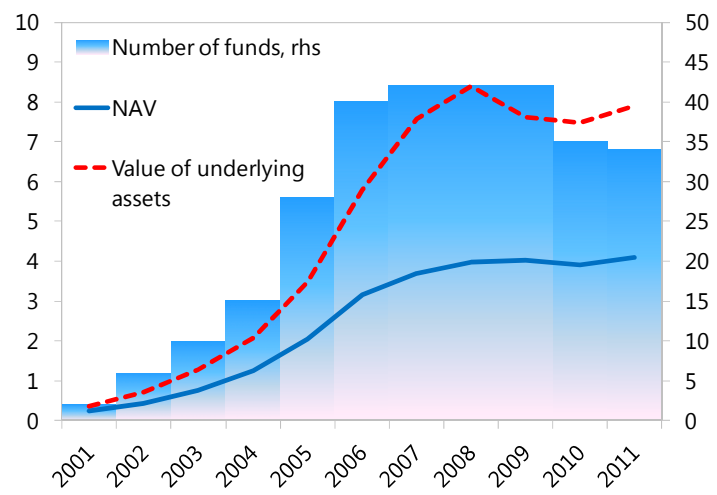

Sources: The Investment Trusts Asspciation, Japan 


\section{- Households have increased housing loans from banks and shifted towards}

flexible-rate mortgages partly due to low interest rates. House price to income ratio has continued to decline and residential property is comparably affordable against other $\mathrm{G} 7$ countries. Demand for housing loans has risen slightly but the share of mortgages in total liabilities remains the lowest among G7 countries at about 50 percent. Private financial institutions, mainly banks, have increased mortgage loans, providing about 82 percent of total mortgages. More than half of outstanding mortgages are in short-term floating rate at one- to two-year duration. Although interest rate risk is somewhat mitigated by possibilities of refinancing to long-term fixed rate loan and under regular (often semiannually) reviews of interest rates, debt-servicing capacity has gradually deteriorated and debt repayment burden could increase if interest rate rose.

\section{B. Corporate Capital Structure}

\section{Corporate capital structure has shifted towards internal financing. Firms-} particularly in the nonmanufacturing sector-have continued to deleverage due to weak growth prospects and excessive borrowing during the 1990's. Firms' capital structure has shifted towards internal financing from surpluses and depreciation expenses with the internal financing ratio increasing from 60 percent to 150 percent during FY2008-FY2010, reverting the gradual downward trend since mid 2000s (Figure 4). ${ }^{4}$ External financing through capital increases has been consistently negative (on average about $¥ 5$ trillion per year) for the past decade due to weak equity markets. As a result, corporate surpluses rose to about 6 percent of GDP.

\section{Figure 4. Japan: Corporate Capital Structure Under Low Interest Rates}

Corporations, particularly nonmanufacturing firms, continue to deleverage...

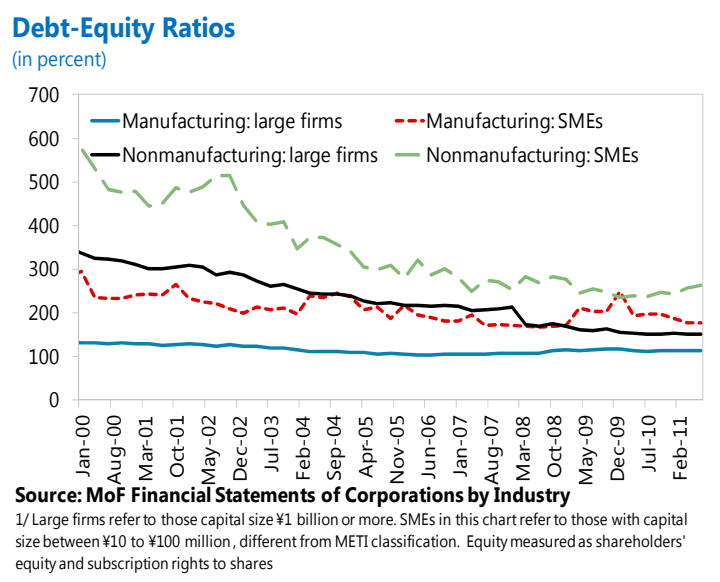

... and have shifted towards internal financing from surpluses and depreciation expenses.

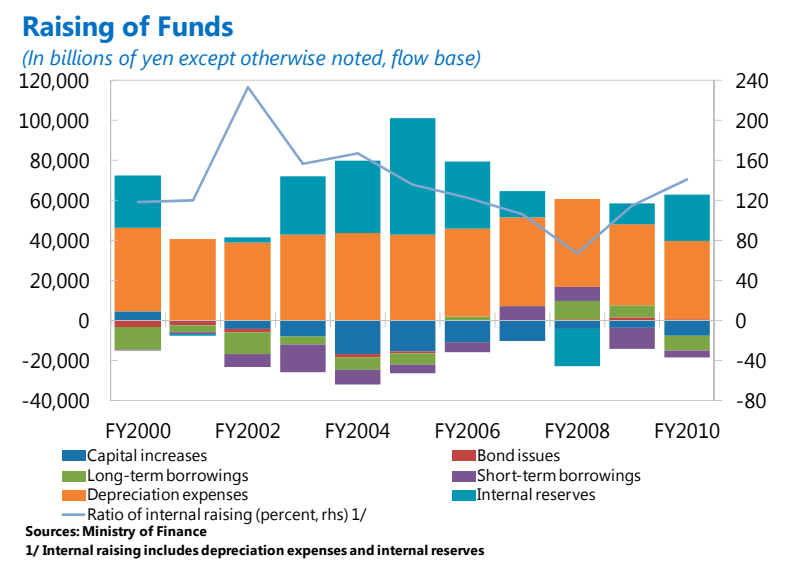

\footnotetext{
${ }^{4}$ Internal financing through reserves and depreciation expenses have been a major source of finance during the past decade. Various studies point to firms' capital structure varies with macroeconomic conditions, and the degree would partly depend on whether firms face financial constraint (Desai, Foley, and Hines, 2004; Fukuda and Hiorta, 1996; Hirota 1999, Korajczyka and Levy, 2003; and Rajan, 1994).
} 
Figure 4. Japan: Corporate Capital Structure Under Low Interest Rates (cont'd)

Nevertheless, nonfinancial corporations' debt remained relatively high among $G 7$.

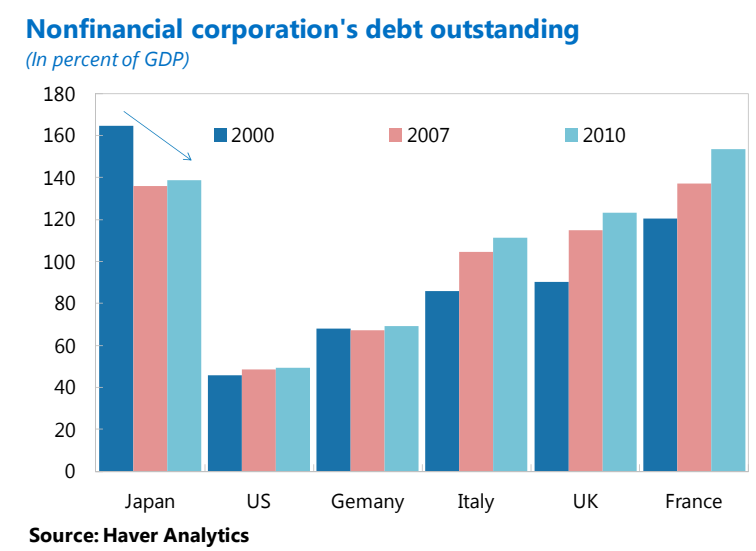

Funding conditions in capital market are favorable and issuances have gradually resumed,...

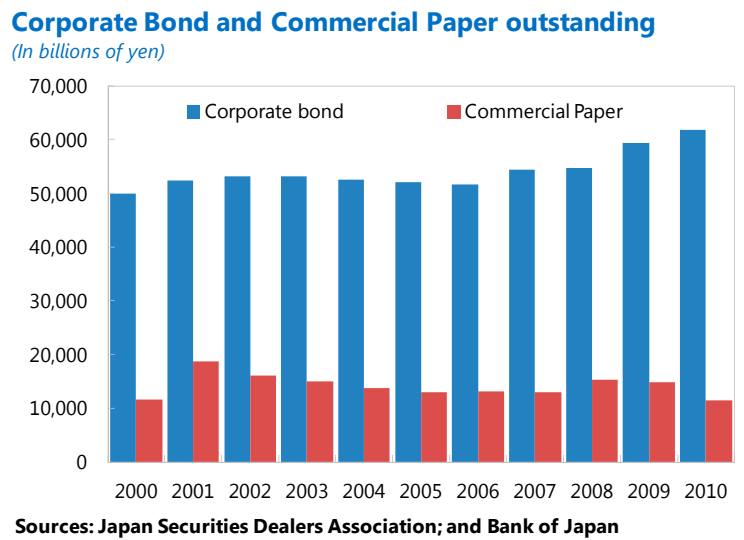

Bank lending to large corporations has somewhat improved but remains weak for SMEs.

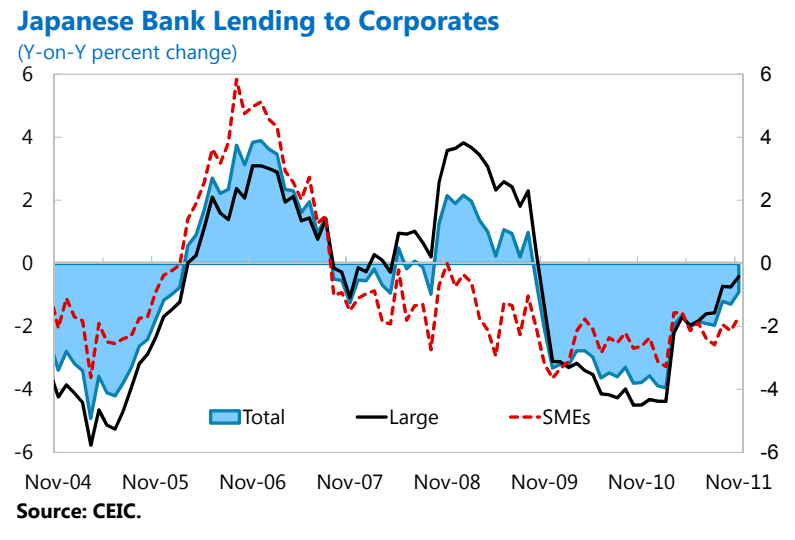

... but markets for asset backed securities remain sluggish.

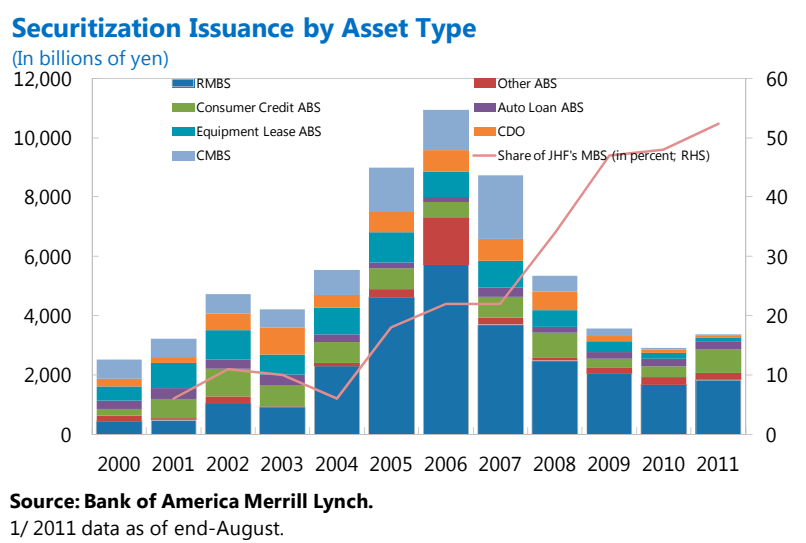

\section{Low interest rates have reduced corporate interest cost and the impact varies} across firm size and sector. Interest cost has been stable at 1.5-2.5 percent of borrowings for large corporations and SMEs, and total interest payment has fallen as firms deleveraged. Lending conditions have eased across firms (including SMEs) but appear to vary across firm size and sector. Preliminary estimates based on corporate financial statements suggest that debt ratios appear to be less responsive to interest rates for manufacturing firms and large firms. For example, a 10 basis point decline of borrowing cost would reduce the debt-equity ratio by 6.5 and 4 percentage points respectively for nonmanufacturing and manufacturing firms, after controlling for their sector and capital size. Possible explanations could be that SMEs and nonmanufacturing firms are more financially constrained, while large corporations are less dependent on debt financing and have a higher return on assets to build up internal funds.

\section{Low interest rates likely contribute to yen carry trades and subdued} securitization activities. Prior to the global financial crisis, part of credit demand is supported by the yen carry-trade activities (about $¥ 1$ trillion), which have largely been 
unwounded as interest differentials narrowed. On the other hand, as credit demand is weak and interest rates are low, there are limited needs for securitization through capital markets by banks. Overall issuances of asset backed securities (ABS) are less than one-third of the pre-crisis level in 2006, except in consumer credits. Despite the overall declining issuances, JHF's issuance of residential mortgage-backed securities (RMBS) has an increasing market share as banks may diversify interest rate risks on housing loans. Commercial mortgagebacked securities (CMBS) issuance is negligible, reflecting sluggish commercial property market and limited investor participation.

\section{Banks’ Business Models}

10. The low interest rate environment and sluggish loan demand have resulted in banks' low core profitability. Shrinking net interest margin on loans (around 0.61.2 percent now relative to about $1.2-2.1$ percent in early $2000 \mathrm{~s}$ ) tends to limit banks' core profitability as interest income accounts for more than two-thirds of total income for banks. As a result, banks' return on assets has stayed below 1 percent in the past few years, lower than that of international banks (Figure 5). Low core profitability also undermines banks' ability to build up retained earnings against shocks and to dispose bad loans. As the gains and losses on securities are in general more volatile than - sometimes more than offseting - net interest income among Japanese banks, such low margins could potentially lead to higher volatility in banks' profits, which could pose risks to profitability (Yamashita and Sakiyama, 2011).

Figure 5. Japan: Shifts of Banks' Business Models Under Low Interest Rates

Returns on assets in the banking system are very modest,...

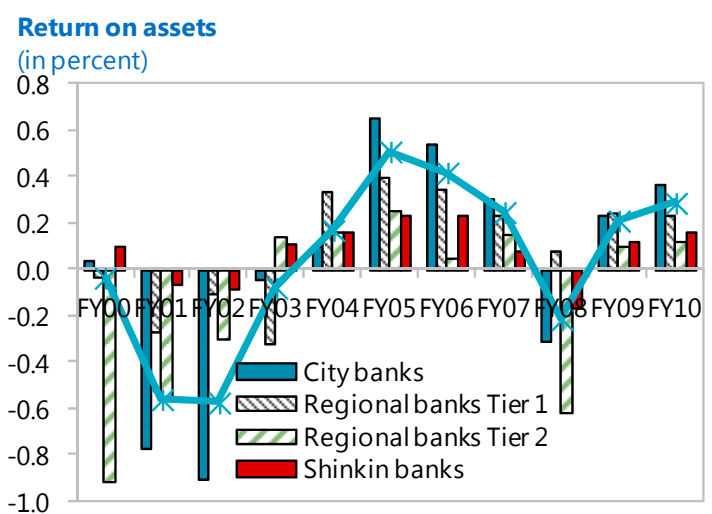

... despite nonperforming loans have significantly declined,...

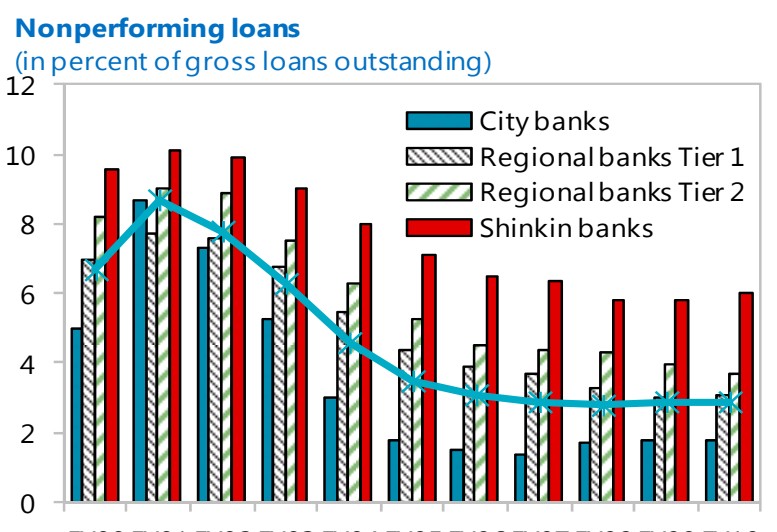

FY00 FY01 FY02 FY03 FY04 FY05 FY06 FY07 FY08 FY09 FY10 
Figure 5. Japan: Shifts of Banks' Business Models under Low Interest Rates (cont'd)

... as the net interest margin shrinks.

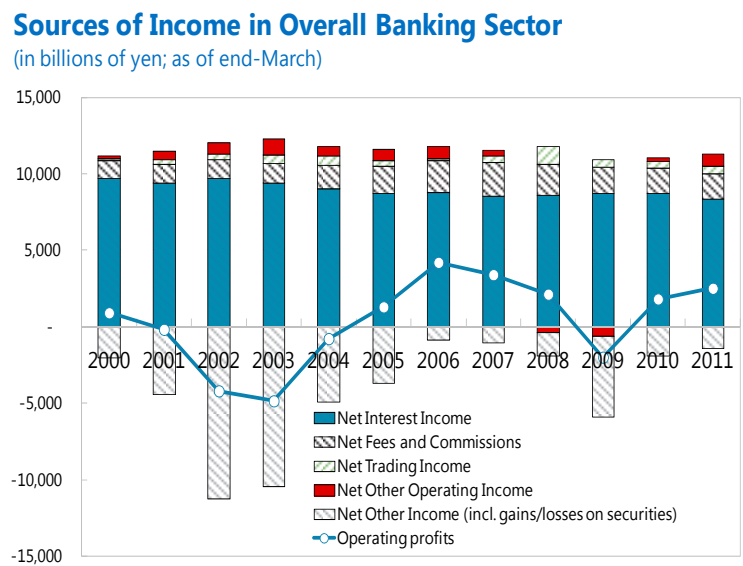

Source: Bank of Japan, CEIC.

... and many foreign banks reduced their presence in Japan, ...

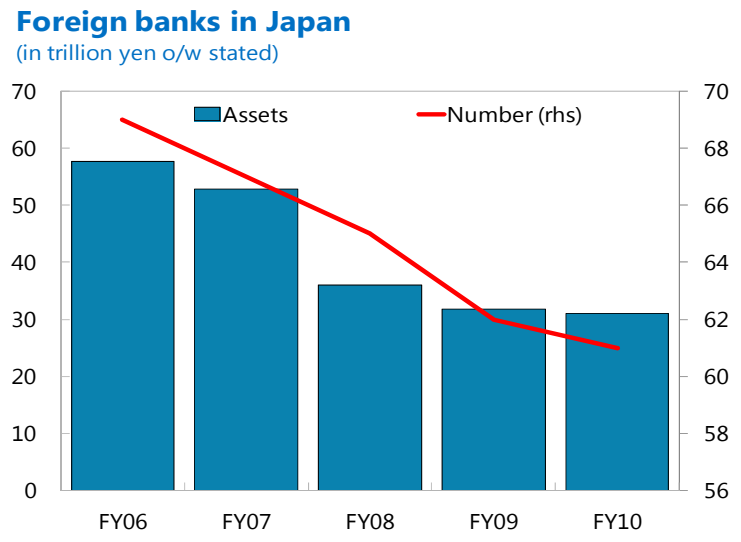

Source: FSA
In response, major banks continue to expand abroad...

Consolidated foreign claims of Japanese banks (in billions of U.S. dollars)

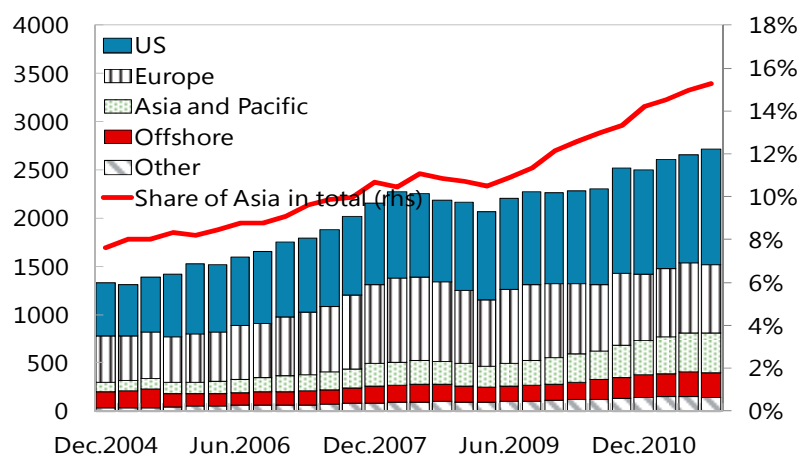

Source: Bank of Japan

Note: On ultimate risk basis. Asia and Pacific includes Australia,

Hong Kong SAR, New Zealand and Singapore.

... but regional banks prospects are linked closely to the regional economies.

Correlation of Regional Banks' Income and Regional Growth (Regional banks, by prefectures)

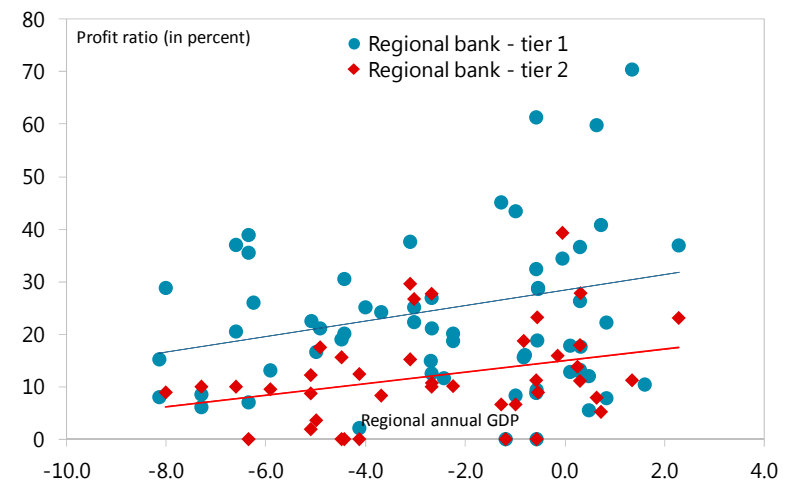

Sources: Japanese Bankers Association and Cabinet Office

\section{Banks' attempts in adjusting business models have so far modest success in enhancing core profitability.}

- Major banks. Overseas expansion has become a part of major banks' business strategies as domestic credit demand remains sluggish. Banks' overseas exposures have increased from about $¥ 20$ trillion to about $¥ 33$ trillion (adjusted for foreign exchange (FX)) during September 2007-2011. Nevertheless, their net interest margin for overseas lending (about 1-3 percent) is not higher than domestic margin due to intense competition with local banks and higher funding cost overseas. ${ }^{5}$ Ongoing

\footnotetext{
${ }^{5}$ Banks usually fund overseas operations through yen liquidity with hedging through FX swaps and currency basis swaps, local retail and corporate deposits, and long-term borrowings. Since Japanese banks have lower credit ratings for overseas funding, the cost of borrowings is usually high. Japanese banks sometimes only earn a small underwriting fee in a project finance and syndicated loan.
} 
deleveraging by European banks has provided takeover opportunities and major Japanese banks are taking a selective approach mainly focusing on investment-grade syndicated loans. Banks have become more susceptible to overseas economies and financial markets.

- Regional and shinkin banks.

Regional banks have increasingly

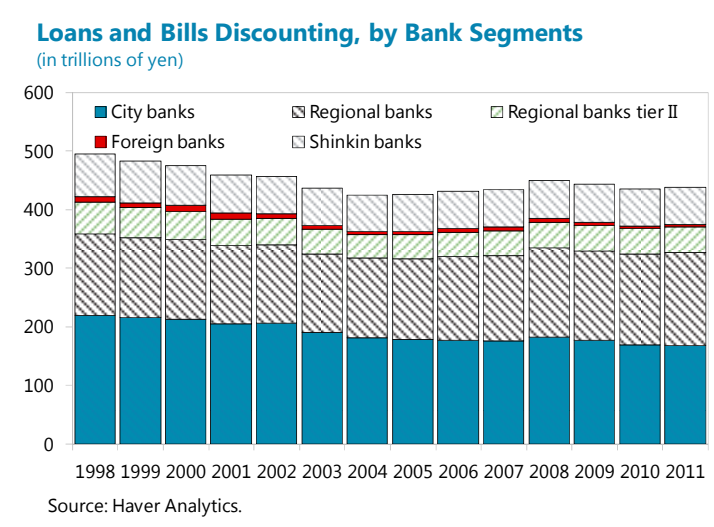

focused on credit to growth sector (e.g., nursing units, supermarkets) and long-term customers, and try to increase loans outside their home prefectures and to large firms in metropolitan areas as well as local governments (Bank of Japan, 2012). Prospects of regional banks critically depend on regional economic developments - banks in prospering prefectures benefit from a rising population and a more diverse industry base, while those in regions with few concentrated industries and declining population face increasing challenges. Developments for shinkin banks (credit cooperatives) are similar, perhaps more acute given their smaller sizes, higher share of risky small business loans, and higher concentration risks in industries and regions.

- Foreign banks. Low interest rates and intense competition have contributed to a declining presence of foreign banks in Japan, both in terms of number of foreign banks in Japan and total assets, over the past few years.

12. In parallel, both major and regional banks have focused on mortgage lending, increasingly offered preferred discount loans with lower base rates such as adjustable rate mortgages. Intensifying lending competition on housing loans and in metropolitan areas has set off a decline in domestic loan rates.

\section{Credit Intermediation: Potential Bottlenecks}

\section{Several policies and structural issues could limit a smooth functioning of credit} intermediation. Current credit conditions are largely constrained by weak credit demand. Reviving credit demand is a challenge and hinges on improved growth prospects. Nevertheless, several areas could potentially carry bottlenecks in credit channels.

\section{A. Government's Role in the Financial System}

14. Multiple policy measures have been put in place in response to various episodes of crisis. Key credit measures include the SME Financing Facilitation Act, relaxation of loan classification criteria among banks, safety-net lending, and expansion of credit guarantees. The BOJ also introduced a lending facility on growth sector (enhanced by asset-based and dollar lending) and in disaster areas (Appendix B). This note focuses on two of those aspects: 


\section{Government credit support measures}

\section{The financial support measures in Japan appear to be broader in scope and} larger in scale relative to other advanced countries. Crisis support measures in Japan are generally broader in scope and longer in duration relative to other advanced countries according to OECD, excluding the disaster-related measures. For instance, credit guarantees account for about 3 percent of GDP each year, while in France and Germany are less than 1 percent of GDP (Figure 6). In Japan, loans with credit guarantees rose sharply to about 8 percent of GDP as of end-FY2010.

\section{Figure 6. Japan: Government Credit Support to the Financial System}

While the presence of GFIs declined over the past decade, they still play an active intermediation role.

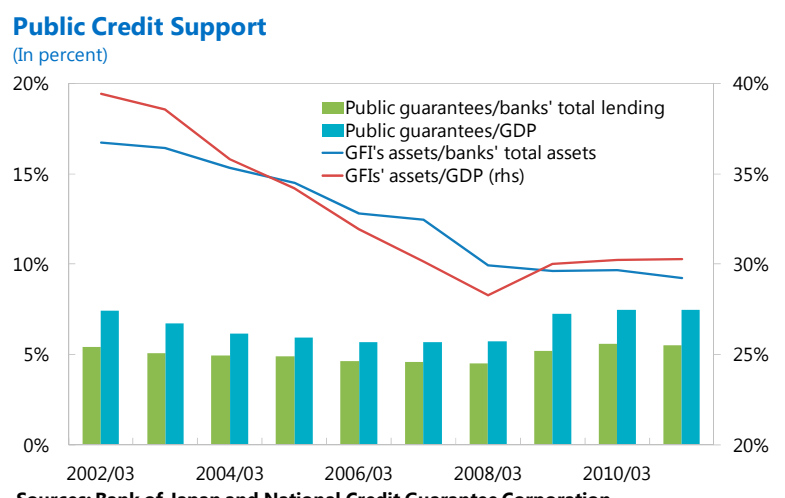

Support measures on guarantees appear to be larger in scale relative to other advanced European countries,...

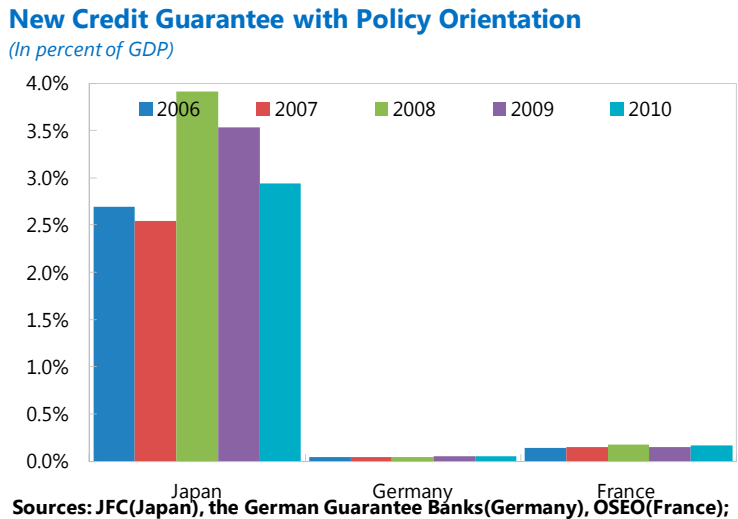
and Haver Analytics
Following the global financial crisis, government substantially extended support measures to SMEs.

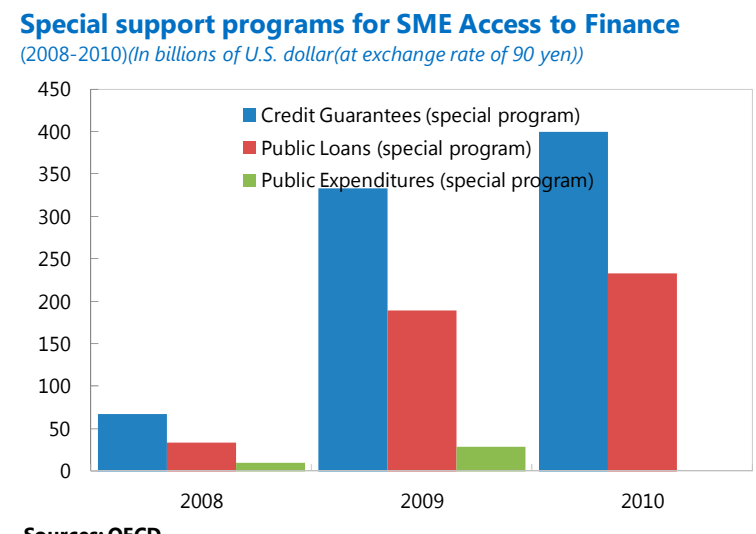

Sources: OECD

..., as well as the United States excluding residential mortgages support.

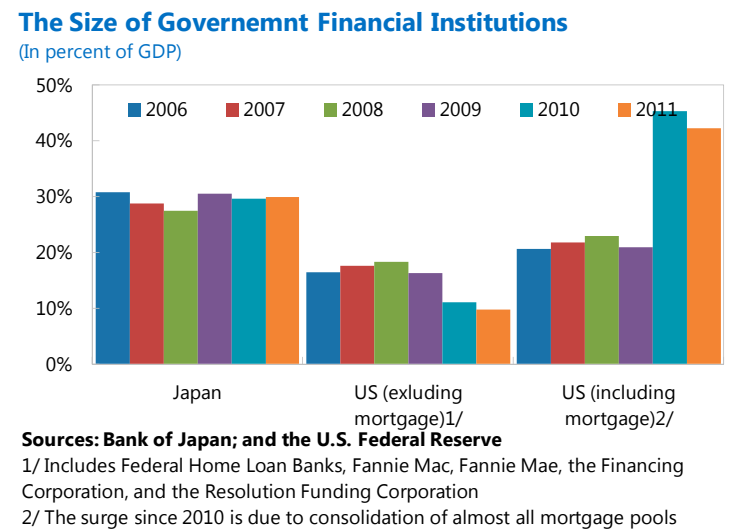


Figure 6. Japan: Government Credit Support to the Financial System (cont'd)

Support measures such as safety-net lending, ...

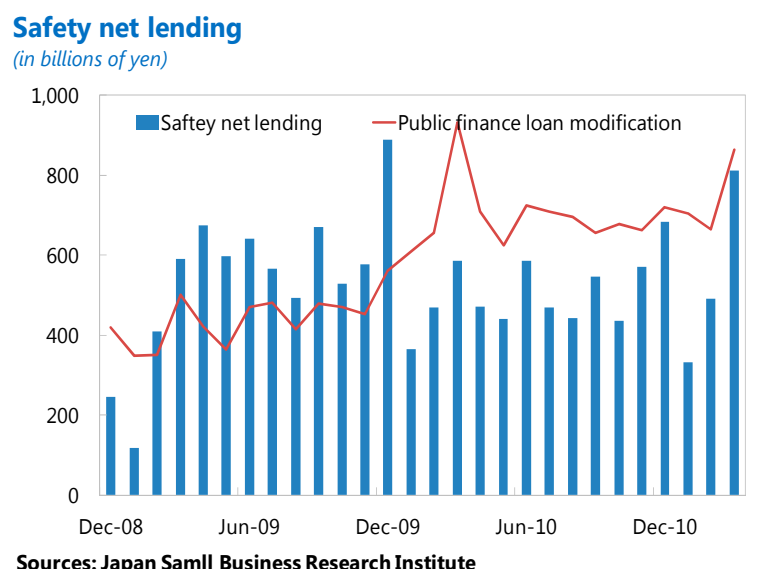

... and sizeable SME guarantees help keep NPLs ratio low.

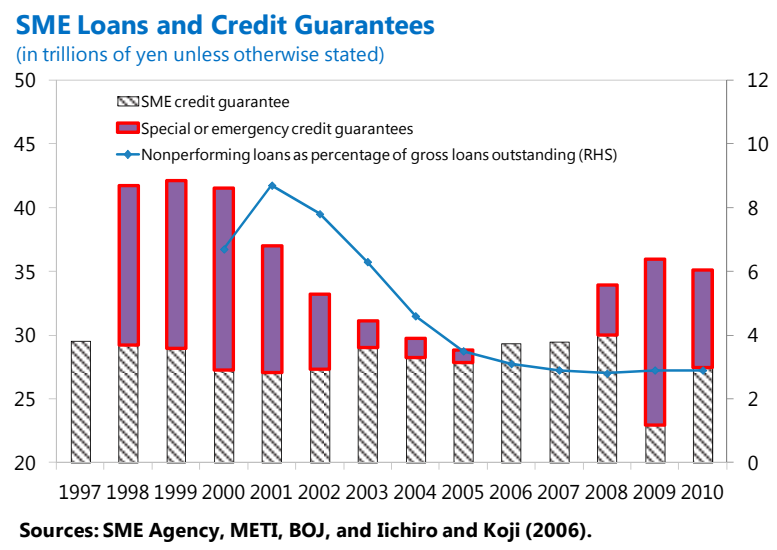

Table 1. Japan: Government Support Programs to Facilitate SMEs Financing, 2008-2011

\begin{tabular}{|c|c|c|c|c|c|c|c|c|}
\hline & \multicolumn{2}{|c|}{$\begin{array}{c}\text { Loan guarantee } \\
\text { programs }\end{array}$} & \multirow[t]{2}{*}{$\begin{array}{l}\text { Strengthening } \\
\text { capital base }\end{array}$} & \multirow[t]{2}{*}{$\begin{array}{l}\text { Direct } \\
\text { credit }\end{array}$} & \multicolumn{3}{|c|}{ Export facilitation } & \multirow[t]{2}{*}{$\begin{array}{l}\text { Credit mediation } \\
\text { and monitoring }\end{array}$} \\
\hline & $\begin{array}{l}\text { Working } \\
\text { capital }\end{array}$ & $\begin{array}{c}\text { Capital } \\
\text { investment }\end{array}$ & & & $\begin{array}{l}\text { Capital } \\
\text { support }\end{array}$ & Credits & $\begin{array}{c}\text { Guarantees / } \\
\text { insurance }\end{array}$ & \\
\hline \multicolumn{9}{|c|}{ Selected OECD countries } \\
\hline Australia & & & $\sqrt{ }$ & & & $\sqrt{ } 3 /$ & $\sqrt{3 /}$ & \\
\hline Canada & $\sqrt{ }$ & $\sqrt{ }$ & $\sqrt{ }$ & $\sqrt{ }$ & $\sqrt{ }$ & $\sqrt{ }$ & $\sqrt{ }$ & \\
\hline Denmark & $\sqrt{ }$ & $\sqrt{ }$ & & $\sqrt{ }$ & $\sqrt{ }$ & $\sqrt{ }$ & $\sqrt{ }$ & Mediation 4/ \\
\hline France & $\sqrt{ }$ & $\sqrt{ }$ & $\sqrt{ }$ & $\sqrt{ }$ & & $\sqrt{ }$ & $\sqrt{ }$ & Mediation \\
\hline Germany & $\sqrt{ }$ & $\sqrt{ }$ & & $\sqrt{ }$ & $\sqrt{ }$ & $\sqrt{ }$ & $\sqrt{ }$ & Mediation \\
\hline Italy & $\sqrt{ }$ & $\sqrt{ }$ & $\sqrt{ }$ & & & $\sqrt{ }$ & $\sqrt{ }$ & Monitoring \\
\hline Japan & $\sqrt{ }$ & $\sqrt{ }$ & $\sqrt{ }$ & $\sqrt{ }$ & $\sqrt{ }$ & $\sqrt{ }$ & $\sqrt{ }$ & \\
\hline Korea & $\sqrt{ }$ & $\sqrt{ }$ & & $\sqrt{ }$ & & & $\sqrt{ }$ & \\
\hline New Zealand & & & & & $\sqrt{ }$ & $\sqrt{ }$ & $\sqrt{ }$ & \\
\hline Portugal & $\sqrt{ }$ & $\sqrt{ }$ & & & & & & \\
\hline Spain & $\sqrt{ }$ & $\sqrt{ }$ & & $\sqrt{ }$ & $\sqrt{ }$ & $\sqrt{ }$ & & Mediation \\
\hline Sweden & $\sqrt{ }$ & $\sqrt{ }$ & $\sqrt{ }$ & & $\sqrt{ }$ & $\sqrt{ }$ & $\sqrt{ }$ & \\
\hline Switzerland & & & & & $\sqrt{ }$ & & & \\
\hline United Kingdom & $\sqrt{ }$ & $\sqrt{ }$ & & $\sqrt{ }$ & & & & \\
\hline United States & $\sqrt{ }$ & $\sqrt{ }$ & & $\sqrt{ }$ & & & & Monitor \\
\hline
\end{tabular}

\section{Role of GFIs}

16. GFIs are important players in the credit channels and have expanded following the global financial crisis (Figure 6). While their share of financial system assets has halved in the past decade, falling to 11 percent as of end-FY2010 (excluding JPB and JPI), GFIs are still active in the credit intermediation through implementing policy directives and facilitating credits to firms that otherwise face financial constraints. Although JPB and JPI do not extend credit, they channel a sizeable private savings and invest those in securities, about 80 percent in JGBs. 
17. The support measures and active role of GFIs have largely sheltered existing firms from a tightening of financing conditions and have prevented widespread bankruptcies (Figure 7).

\section{Figure 7. Japan: Benefits and Costs of Government Support Measures}

Most SMEs consider the SME Financing Facilitation Act has helped improve their business, ...

Assessment of impact of SME Financing Facilitation Act on own business (In percent of total survey responses)

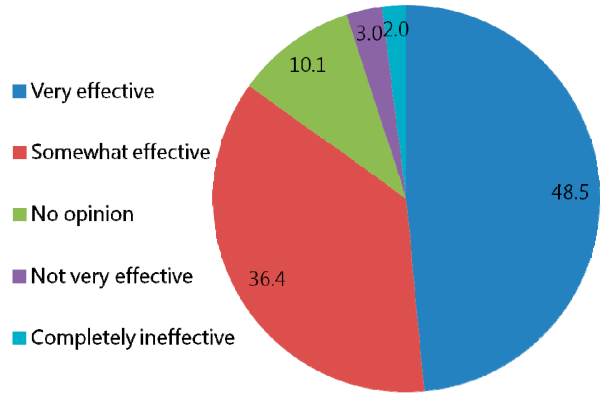

Sources: Japan Small Business Research Institute

Financial institutions also see some benefits of loan modification measure in easing lending attitudes.

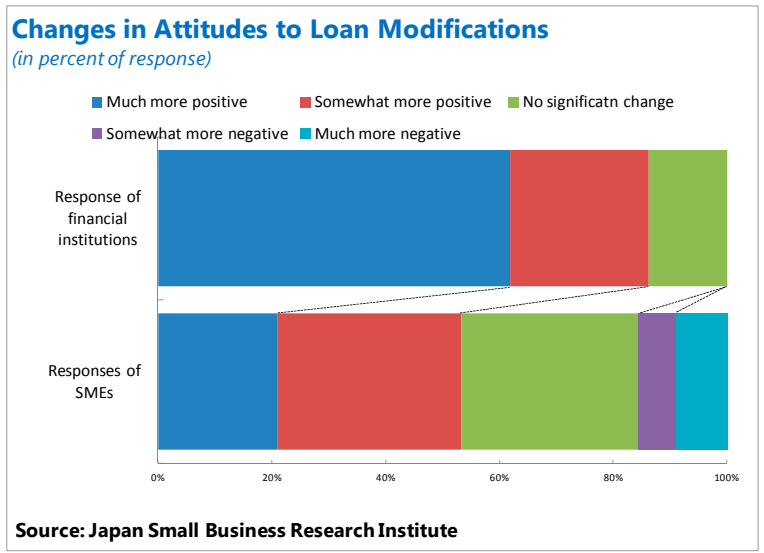

...such as limiting layoffs, preventing bankruptcies and a deterioration of financing conditions.

Impact had there been no SME Financing Facilitation Act (in percent of responses)

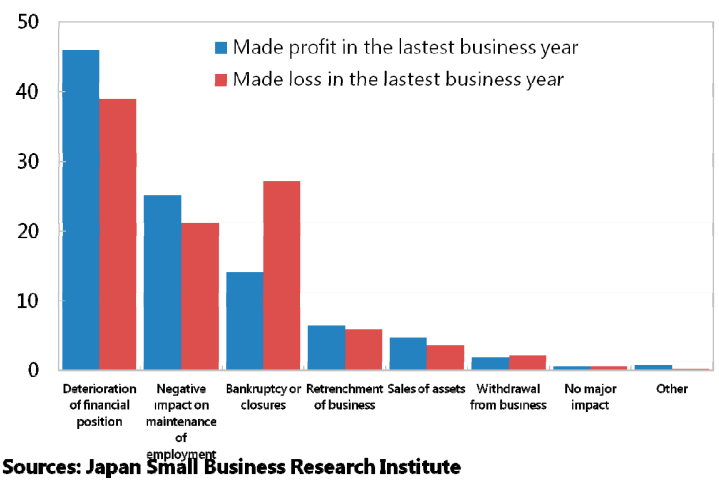

But nearly half of SMEs use counter-cyclical guarantees to bolster liquidity, rather than encourtering financing difficulties.

Reasons for uses of the Counter-cyclical Emergecy Guarantee Prorgram (Percent 1/)

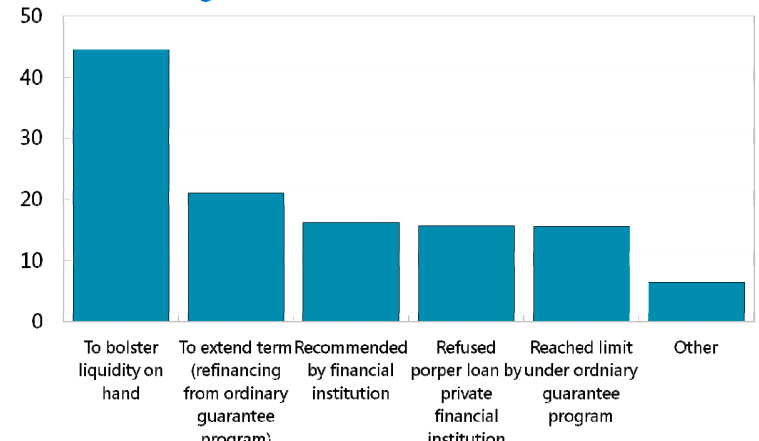

Sources: Japan Smalligurami

$1 /$ multiple responses 
Figure 7. Japan: Benefits and Costs of Government Support Measures (cont'd)

Many SMEs also see potential negative impact on future new borrowing under the loan modification, ...

Reasons for not applying for loan modification
(In percent of responses)

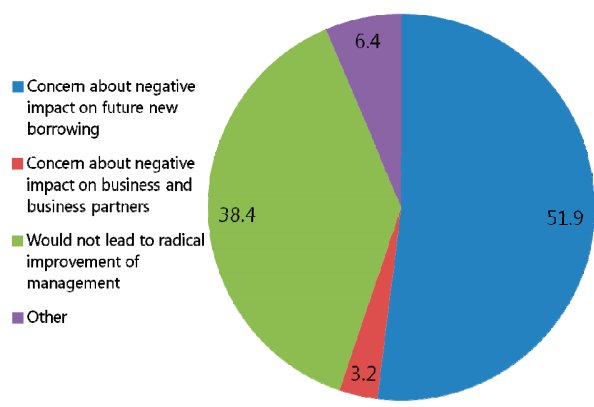

Sources: Japan Small Business Research Institute ...which may also weaken the credit risk assessment by financial institutions.

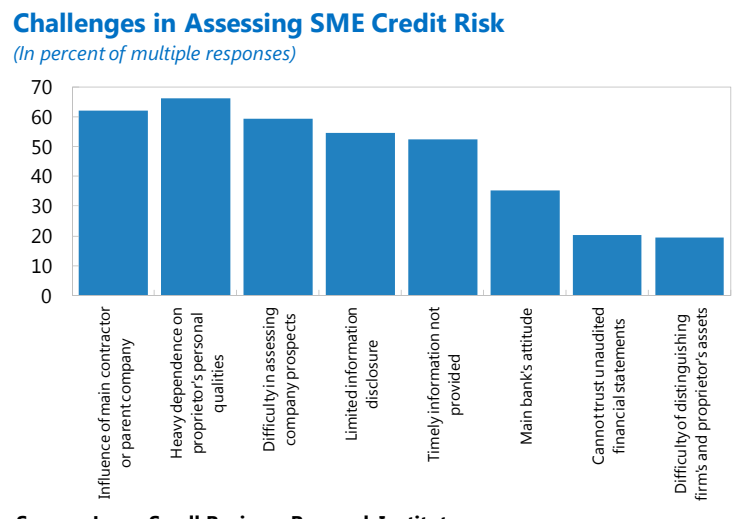

Source: Japan Small Business Research Institute

- Smooth financing conditions and credit availability. According to survey results, more than 60 percent of financial institutions find that the SME Financing Facilitation Act helps improve lending attitudes. Empirical studies also find that the credit guarantee program has improved credit availability to existing SMEs (Uesugi, 2008; Ono, Uesugi, and Yasuda, 2010 and 2011). Nearly half of SMEs used countercyclical guarantees to bolster liquidity, and more than one-fifth have extended their guarantee terms. As a result, the overall nonperforming loans ratio has remained stable at about 2 percent after the global financial crisis and the disaster, despite large fall in output.

- $\quad$ Prevent widespread layoffs and bankruptcies. The measures partly explain the gradual decline in bankruptcies by an average of 12 percent after the peak of Lehman crisis, and a low corporate exit rate, hovering at 4-5 percent. Unemployment has not substantially risen after the global financial crisis and the disaster.

- Swift response to shocks. The active role of GFIs in channeling credit (nearly 10 percent of SME credit) has ameliorated adverse shocks.

18. At the same time, several policy measures entail direct fiscal cost and other indirect costs that begin to outweigh benefits:

- $\quad$ Fiscal cost. Direct fiscal cost includes capital injections to GFIs, sizeable credit support measures. This adds to fiscal burden as gross public debt level reaches above 200 percent of GDP. For indirect fiscal cost, the government may face contingent liabilities arising from reinsuring credit guarantees and from funds provided to GFIs for further capital injection (see below).

Weaken credit risk assessment. Measures for loan reclassification are likely to affect negatively on banks' credit risk assessment by understating the actual credit 
risks. About $¥ 12.5$ trillion of doubtful and substandard assets were classified as normal, which could increase credit risk if banks do not maintain a stringent risk assessment. If the firms with restructured loans were not able to recover their business conditions, banks' nonperforming loans could rise by about 1 percentage point (Bank of Japan, 2012), and the problem appears more severe among regional and credit cooperatives as a higher proportion of their loans is reclassified under the Act (about 3-6 percent of total credit in regional banks and credit cooperatives relative to 1.7 percent in major banks).

Japan: Loan Classification in Banks

\begin{tabular}{|c|c|c|c|c|c|c|c|c|}
\hline $\begin{array}{l}\text { Self assessment } \\
\text { classification }\end{array}$ & Rating & Borrower rating criteria & $\begin{array}{l}\text { FRA disclosure } \\
\text { category } 1 /\end{array}$ & $\begin{array}{l}\text { Risk monitored asset } \\
\text { category }\end{array}$ & $\begin{array}{l}\text { Major } \\
\text { banks }\end{array}$ & $\begin{array}{l}\text { Regional } \\
\text { banks }\end{array}$ & $\begin{array}{l}\text { Credit } \\
\text { cooper- } \\
\text { atives }\end{array}$ & Total \\
\hline \multirow[t]{2}{*}{ Normal } & $A$ & $\begin{array}{l}\text { Extremely high probability of redemption, extremely } \\
\text { stable from credit exposure management }\end{array}$ & \multirow[b]{2}{*}{ Normal loans } & & \multirow[b]{2}{*}{252.6} & \multirow[b]{2}{*}{204.4} & \multirow[b]{2}{*}{86.4} & \multirow[b]{2}{*}{543.4} \\
\hline & $\begin{array}{l}\text { B } \\
\text { C } \\
\text { D }\end{array}$ & $\begin{array}{l}\text { No near-term issue in terms of redemption likelihood, } \\
\text { sufficiently stable from credit exposure management } \\
\text { No near-term issues in terms of redemption likelihood, } \\
\text { credit exposure management } \\
\text { No problem at present with redemption, but susceptible } \\
\text { to future changes }\end{array}$ & & Normal loans & & & & \\
\hline \multirow{2}{*}{ Caution } & \multirow{2}{*}{$\mathrm{E}$} & $\begin{array}{l}\text { Debtors with interest waivers/payments on hold, or } \\
\text { other problems meeting lending terms. Debtors with }\end{array}$ & \multirow{2}{*}{$\begin{array}{l}\text { Special attention } \\
\text { loans }\end{array}$} & Restructured loans & \multirow{3}{*}{1.5} & \multirow[b]{2}{*}{1.0} & \multirow[b]{2}{*}{0.5} & \multirow{3}{*}{2.9} \\
\hline & & $\begin{array}{l}\text { delinquent loan repayments or interest payments or } \\
\text { other redemption issues. Debtors requiring caution due } \\
\text { to weak or unstable business conditions. }\end{array}$ & & $\begin{array}{l}\text { Past due loans more } \\
\text { than } 3 \text { months } 2 /\end{array}$ & & & & \\
\hline Doubtful & $\mathrm{F}$ & $\begin{array}{l}\text { Debtor is not bankruptcy but in difficulty, progress on } \\
\text { business plans is poor and business may fall into } \\
\text { bankruptcy }\end{array}$ & Doubtful loans & \multirow{2}{*}{$\begin{array}{c}\text { Past due loans } \\
\text { exclusive of accrued } \\
\text { interest } 3 /\end{array}$} & & 4.0 & 3.0 & \\
\hline $\begin{array}{l}\text { Virtual } \\
\text { bankruptcy }\end{array}$ & G & $\begin{array}{l}\text { Debt is not legally or formally in a bankruptcy state, but } \\
\text { business is in serious trouble. There appear no prospects } \\
\text { for restructuring. }\end{array}$ & \multirow{2}{*}{$\begin{array}{l}\text { Bankrupt or de- } \\
\text { facto bankrupt } \\
\text { loans }\end{array}$} & & \multirow[b]{2}{*}{0.6} & \multirow[b]{2}{*}{1.7} & \multirow[b]{2}{*}{1.7} & \multirow[b]{2}{*}{4.0} \\
\hline Legal bankruptcy & $\mathrm{H}$ & Debtor is legally and formally bankrupt & & $\begin{array}{l}\text { Loans to borrowers } \\
\text { declared bankrtupt or } \\
\text { similar circumstances } \\
4 /\end{array}$ & & & & \\
\hline \multicolumn{9}{|c|}{ Memorandum items: } \\
\hline \multirow{2}{*}{\multicolumn{5}{|c|}{$\begin{array}{l}\text { Total credits } \\
\text { Loans under Financial Reconstruction Act (in percent of total credits) }\end{array}$}} & 257.0 & 211.1 & 91.5 & 559.6 \\
\hline & & & & & 1.7 & 3.2 & 5.6 & 2.2 \\
\hline \multicolumn{9}{|c|}{ Source: FSA and Nikko Citigroup Limited. } \\
\hline \multicolumn{9}{|c|}{ 1/ Financial Reconstruction Act. } \\
\hline \multicolumn{9}{|c|}{ 2/ Loans in arrears by more than 3 months that do not fall into the above two categories. } \\
\hline \multicolumn{9}{|c|}{ 3/ Past due loans exclusive of accrued interest. This category excludes loans on which interest is being waived in support of business restructuring. } \\
\hline \multicolumn{9}{|c|}{$\begin{array}{l}\text { 4/ Loans to borrowers declared bankrupt, to borrowers under rehabilitation, to borrowers under reorganization, or other similar circumstances, } \\
\text { which are part of loans exclusive of accrued interest. }\end{array}$} \\
\hline
\end{tabular}

- Widespread credit guarantees could weaken credit intermediation by reducing credit availability for nonguaranteed loans (as banks switched to guaranteed loans), limiting banks' incentives for risk assessment, and increasing credit linkages among regional banks, SMEs, and local governments (Choe 2006; Honjo and Harada, 2006; Ono, Uesugi, and Yasuda, 2011; and Uesgui and Sakai, 2005). ${ }^{6}$

\footnotetext{
${ }^{6}$ Under the credit guarantee program, private financial institutions extend loans to SMEs, which could in turn seek credit guarantees from the 52 local credit guarantee corporations (CGCs) at a low fee about 1.15 percent (or 0.8-1.0 percent under special guarantees). The local CGCs in turn pay a premium to reinsure the SME loans with the JFC, a fully-owned GFI. About 70-80 percent of CGCs' subrogated performance payments are made by JFC through insurance contracts. Average loan maturity is five to seven years with the normal guarantee covering 80 percent of the loan, while special guarantee covers 100 percent with the maximum duration of ten
} 
Estimates of previous special guarantee program in late 1990s and early $2000 \mathrm{~s}$ find that the cost was large relative to the size of guaranteed credit (around $¥ 2.1$ trillion or $1 / 2$ percent of GDP, Koo and Sasaki, 2010).

- $\quad$ Other indirect costs. Over half of SMEs did not apply for loan modification on concerns of negative impact on future new borrowing, according to the SME surveys (Figure 7). Credit support measures could result an unintended consequence of keeping nonviable SMEs afloat (e.g., accommodative terms of credit guarantees tend to limit incentives for SME restructuring), as evidenced by the low exit and business transfer rates despite the weak profitability among SMEs (Section III.B).

\section{The presence of GFIs in credit intermediation could add contingent liabilities to}

the fiscal position. The government could face contingent liabilities, such as losses from credit guarantees through fund-provision to Japan Finance Corporation's reinsurance and subsidies for compensation assets in National Federation of Credit Guarantee Corporation (FCGC) and other CGC funds (in-text figure), which could reach $¥ 1$ trillion. In addition, delays and uncertainty on the GFI reform agenda could further undermine some GFI's business strategies in achieving their mandates and create difficulties in supervision (Appendix C). Higher share of loans channeled by public financial institutions tend to hinder

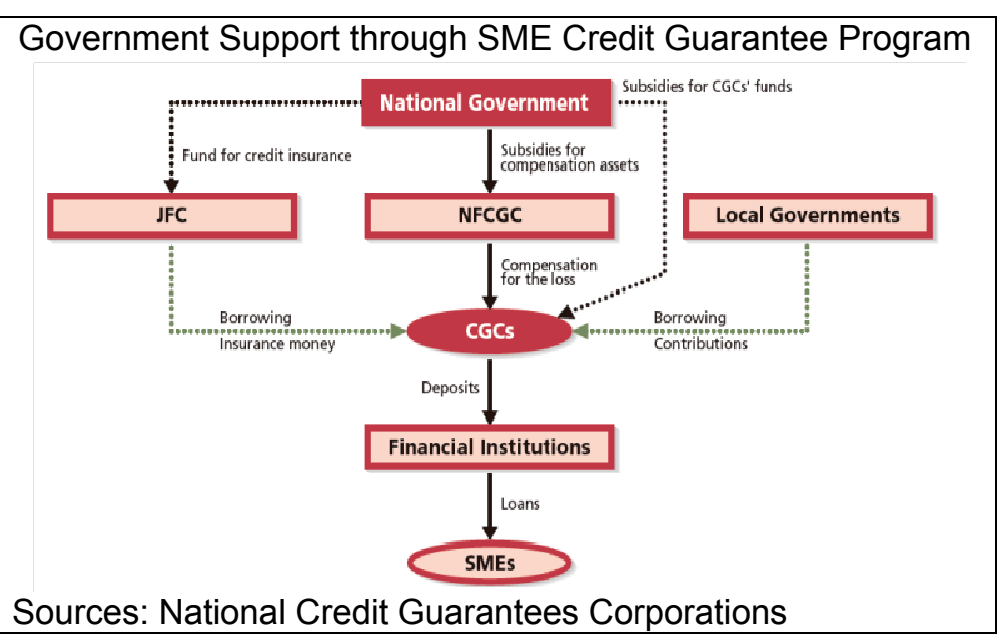
capital market development to supply risk money and prevent exit of less competitive firms (OECD 2006; and World Bank Group, 2010).

\section{Reforms on GFI s have taken place since the last FSAP, but the momentum has} slowed and gaps exist in terms of ensuring a level-playing field. Reforms to improve transparency and efficiency of GFIs were put in place, many of which are in line with the previous Financial Sector Assessment Program (FSAP) recommendations (Appendix C). However, many reform agenda were revised after the global financial crisis. The scope and timing for the full privatization of Japan Post were fully suspended in 2009, while the commencement phrase for the full privatization of SCB and DBJ were extended to begin in

years (relative to the international average of 60 percent). Guaranteed loans to existing SMEs are often rolled over. Guarantee fees appear relatively low, ranging from 0.45 to 1.90 percent according to nine risk categories, and are seldom reviewed (e.g., once every five years for variable-rate loan). Guarantee fees on special guarantee are further lower, set at about $0.75-0.80$ percent of the loan amount. 
later years of the decade. ${ }^{7}$ While most GFIs are not subject to public subsidy in setting interest rates, some GFIs' lending rates apparently vary below market costs. Several GFIs (excluding the Japan Post Bank and Insurance) are not subject to corporate tax and capital requirements under respective acts. In addition, although GFIs are often under joint supervision by multiple ministries and the inspection authority was mostly delegated to the FSA after the reform in 2002, inspections were rather infrequent at about once every two to three years (Table 2).

\footnotetext{
${ }^{7}$ For SCB, the commencement of the full privatization term was extended by three and a half years due to global financial crisis and by three more years after the Great East Japan Earthquake. For DBJ, the scheduled full privatization plan (initially within 5-7 years from 2015) was twice extended in 2009, and in 2011. The government also reserve rights to review the process by end-FY2014.
} 
Table 2. Japan: Comparison of Selected Government-Affiliated Financial
Institutions (GFIs)

\begin{tabular}{|c|c|c|c|c|}
\hline Categories & $\begin{array}{c}\text { Japan Housing } \\
\text { Finance Agency } \\
\text { JHF } \\
\end{array}$ & $\begin{array}{c}\text { Japan Finance } \\
\text { Corporation } \\
\text { JFC } \\
\end{array}$ & $\begin{array}{c}\text { Development Bank of } \\
\text { Japan } \\
\text { DBJ }\end{array}$ & $\begin{array}{c}\text { Shoko Chukin Bank } \\
\text { SCB }\end{array}$ \\
\hline Mandate & $\begin{array}{l}\text { Support orgination of long- } \\
\text { term fixed rate housing } \\
\text { loans by private financial } \\
\text { institutions }\end{array}$ & $\begin{array}{l}\text { Complement private } \\
\text { financial services in credit } \\
\text { intermediation }\end{array}$ & $\begin{array}{l}\text { Contribute to smooth supply } \\
\text { of funds to those who need } \\
\text { long-term business funds, as } \\
\text { well as to the sophistication of } \\
\text { financial functions }\end{array}$ & Facilitate SME financing \\
\hline Funding & $\begin{array}{l}\text { Mainly by issuing } \\
\text { mortgage-backed } \\
\text { securities (MBS) }\end{array}$ & $\begin{array}{l}\text { Mainly Fiscal Investment } \\
\text { and Loan Program (FILP) }\end{array}$ & $\begin{array}{l}\text { Mainly by issuing bonds with } \\
\text { and without government } \\
\text { guarantees and long-term } \\
\text { private borrowing }\end{array}$ & $\begin{array}{l}\text { Deposit, long- and short-term } \\
\text { debentures and borrowing }\end{array}$ \\
\hline History & $\begin{array}{l}\text { Established in 1950; } \\
\text { incorporated in } 2007 .\end{array}$ & $\begin{array}{l}\text { Several GFIs were } \\
\text { integrated to form the JFC } \\
\text { in Oct } 2008 .\end{array}$ & $\begin{array}{l}\text { Formed in } 1999 \text { and } \\
\text { incorporated in } 2008\end{array}$ & $\begin{array}{l}\text { Established in 1936; } \\
\text { incorporated in } 2008 \text {. }\end{array}$ \\
\hline Reform plan & None & None & $\begin{array}{l}\text { The Initial plans to fully } \\
\text { privatize the bank in 5-7 years } \\
\text { after incorporation now } \\
\text { extended to approximately 5-7 } \\
\text { years from April } 2015\end{array}$ & $\begin{array}{l}\text { The Initial plans to fully } \\
\text { privatize the bank in 5-7 years } \\
\text { after incorporation now } \\
\text { extended to approximately 5-7 } \\
\text { years from April } 2015\end{array}$ \\
\hline $\begin{array}{l}\text { Profit arrangement } \& \\
\text { dividend policy }\end{array}$ & $\begin{array}{l}\text { Excess of reserve funds } \\
\text { is set aside for mid-term } \\
\text { plan. }\end{array}$ & $\begin{array}{l}\text { Excess of reserve funds } \\
\text { are returned to the } \\
\text { government. }\end{array}$ & $\begin{array}{l}\text { Profits are transferred to the } \\
\text { government as dividends, but } \\
\text { the government does not } \\
\text { assume losses. }\end{array}$ & $\begin{array}{l}\text { Profits are shared according to } \\
\text { ownership share. Dividend for } \\
\text { shares held by the government } \\
\text { is } 1 / 3 \text { of dividend for non- } \\
\text { government shareholders. }\end{array}$ \\
\hline Corporate tax & No $1 /$ & No $1 /$ & Yes & Yes \\
\hline Insolvency regime & $\begin{array}{l}\text { Insolvency law not } \\
\text { applicable } 2 /\end{array}$ & Insolvency law applicable & Insolvency law applicable & Insolvency law applicable \\
\hline Capital requirement & No & No & No $3 /$ & Yes 4I \\
\hline Capital structure & $\begin{array}{l}\text { Capital fully provided by } \\
\text { the government. }\end{array}$ & $\begin{array}{l}\text { Capital fully provided by } \\
\text { the government. }\end{array}$ & $\begin{array}{l}\text { Capital fully provided by the } \\
\text { government. }\end{array}$ & $\begin{array}{l}\text { Shareholders restricted to the } \\
\text { government (about } 46.5 \\
\text { percent as at end-Sep 2009), } \\
\text { SME cooperatives and } \\
\text { members. }\end{array}$ \\
\hline Reserve requirement & No & No & No & No \\
\hline Accounting & $\begin{array}{l}\text { According to Incorporated } \\
\text { Administrative Agency } \\
\text { (IAA) Procedure Act and } \\
\text { respective principles. }\end{array}$ & J-GAAP & J-GAAP & J-GAAP \\
\hline Supervision & MLIT and MOF & $\begin{array}{l}\text { MOF,METI, MHLW and } \\
\text { MAFF }\end{array}$ & $\begin{array}{l}\text { MOF and FSA(as an financial } \\
\text { instrument provider) }\end{array}$ & METI, MOF, and FSA \\
\hline Inspection 5/ & MLIT, MOF and FSA & $\begin{array}{l}\text { MOF, METI, MHLW, } \\
\text { MAFF and FSA }\end{array}$ & MOF and FSA & METI, MOF, and FSA 6/ \\
\hline Basic Law & $\begin{array}{l}\text { Japan Housing Finance } \\
\text { Agency Act }\end{array}$ & $\begin{array}{l}\text { Japan Finance } \\
\text { Corporation Act }\end{array}$ & $\begin{array}{l}\text { Development Bank of Japan } \\
\text { Act }\end{array}$ & $\begin{array}{l}\text { Shoko Chukin Bank Limited } \\
\text { Act }\end{array}$ \\
\hline
\end{tabular}

\section{Source: Japanese authorites}

1/ JHA and JFC have no obligation for corporate tax.

$2 /$ Insolvency law is not applicable as JHF is an incorporated administrative agency.

$3 / \mathrm{DBJ}$ has no capital requirement but discloses its capital adequacy ratio based on the Banking Act.

4/ SCB has certain capital requirement under the Shoko Chukin Bank Limited Act.

$5 /$ The authority of on-site inspection to the government financial institutions is delegated from various Ministries to the

Commissioner of the FSA. The scope of delegated authority is stipulated as regarding the management of the risk of losses in their

operations.' The inspection is conducted with an objective to facilitate GFIs' superivision.

6/ The incorporation of Shoko Chukin Bank provided the FSA the authority of supervision and inspection.

\section{B. Structural Weakness of SMEs}

\section{In Japan, SMEs are socially and economically important but they face structural} weaknesses of low profitability and high leverage. SMEs account for nearly 70 percent of total employment and over half (about 53 percent) of manufacturing value-added, and their viability is closely linked to the regional economies. The SME sector has been deleveraging over the past decade, particularly for nonmanufacturing firms, but their debt-equity ratio (at 250-300 percent; 2.5 times higher than large corporations) remains high and profitability is low (three times less than large corporations). The return on assets (ROA) for SMEs is 
around 1 percent, significantly lower than those in Germany and France at about 5 percent and 3 percent, respectively (Tokuda, 2011). Interest coverage ratio for SMEs, an indicator of debt servicing capacity, has been below 1 and downside disparity has increased (Figures 4 and 8, and Table 3). As a result, many SMEs entered the global financial crisis with weaker balance sheets. While the interest costs across all SMEs are not significantly different, lower risk-rating SMEs have at least 5 times less interest coverage than strong riskrating counterparts (Table 4).

\section{Figure 8. Japan: Structural Weakness of SMEs Under Low Interest Rates}

\section{Labor productivity in SMEs has leveled off for more than a decade.}

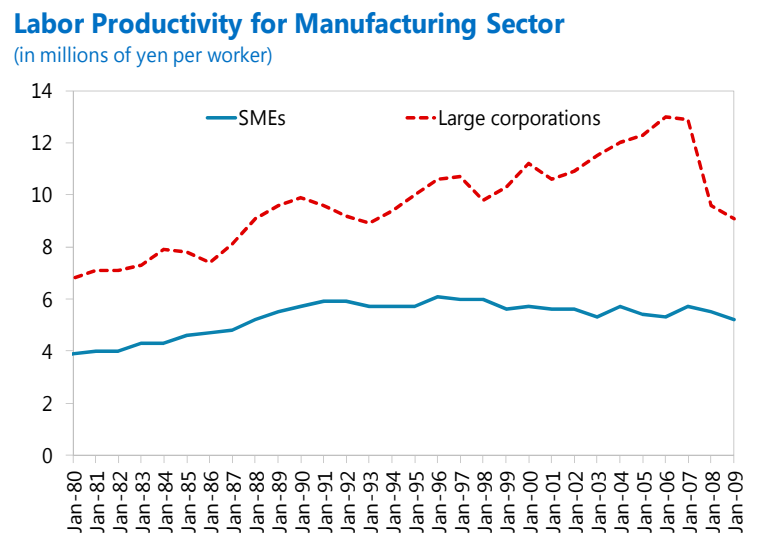

\section{Source: Ministry of Finance.}

SMEs with credit guarantees are less profitable and have weaker repayment capacity on loans...

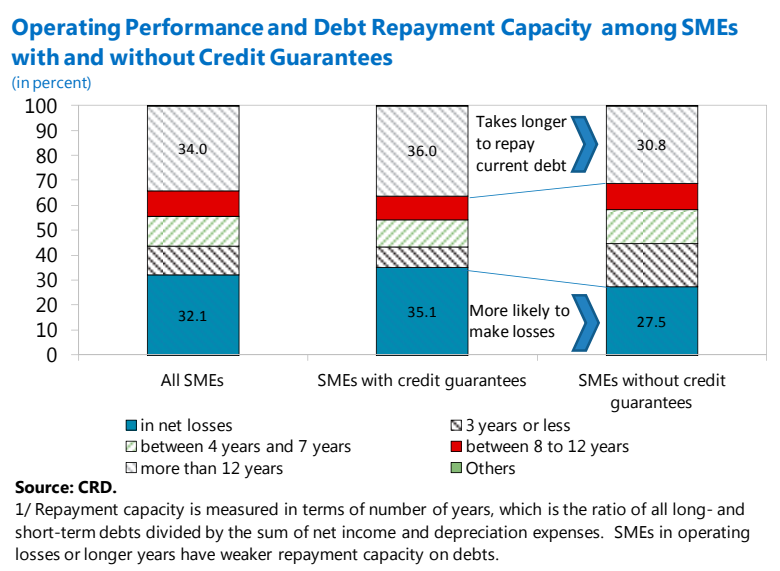

Interest rate coverage for SMEs remains low despite reduced borrowing cost.

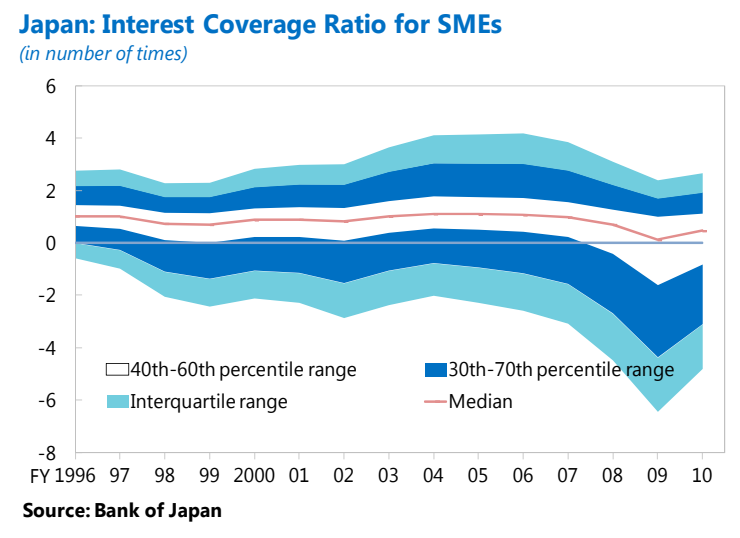

Most SMEs see weak demand as the challenge, while difficulty of raising funds is not a key concern.

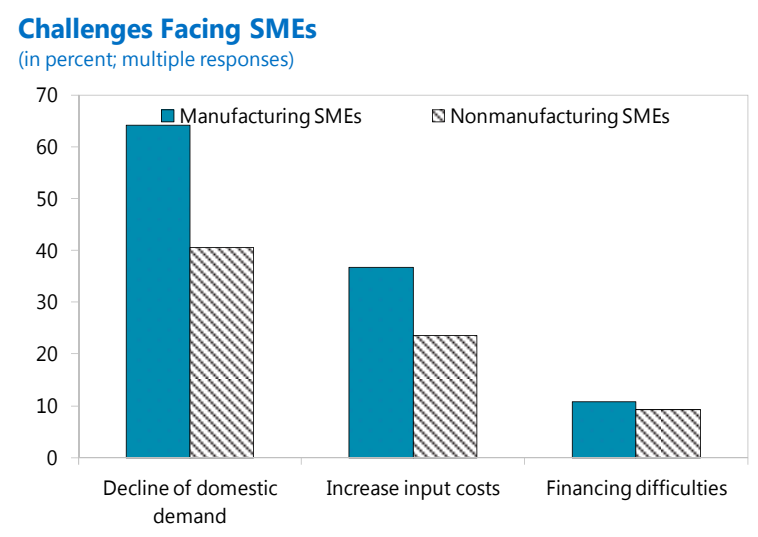

Source: Japan Small Business Research Institute. 
Figure 8. Japan: Structural Weakness of SMEs Under Low Interest Rates (cont'd)

Looking forward, measures appear to be more effective in supporting demand and transfers than financing.

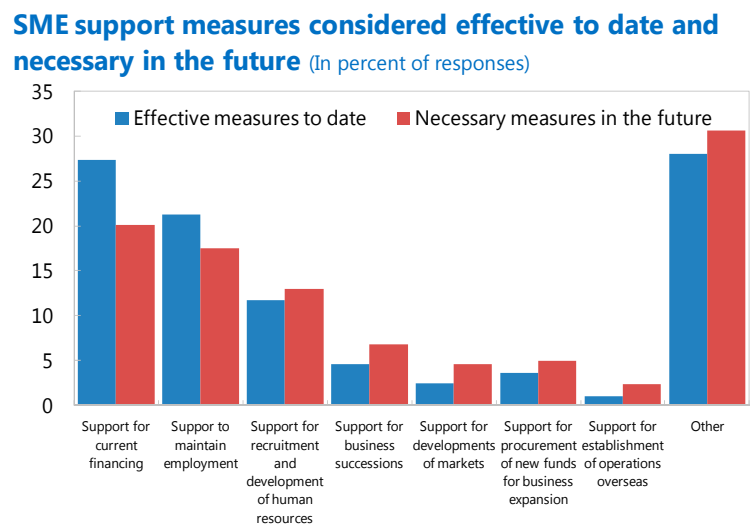

Developing new sources of demand and raising productivity are key areas for improving SME prospects.

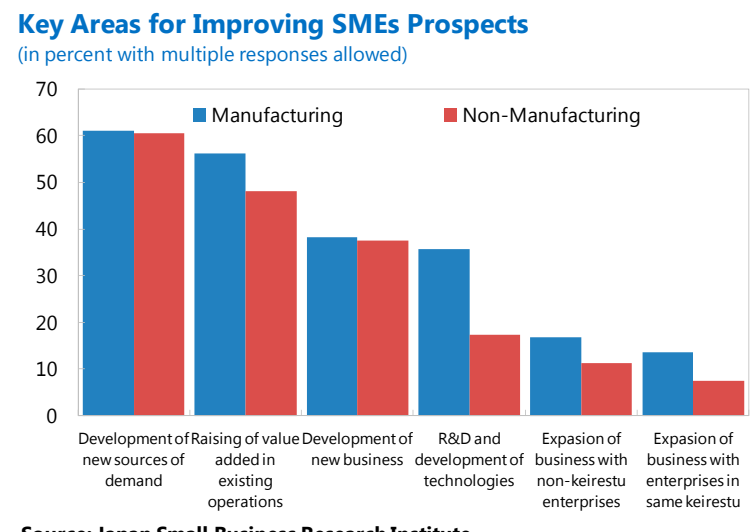

\section{Table 3. Japan: Summary Statistics of the Corporate Sector-By Industry and Capital Size}

\begin{tabular}{|c|c|c|c|c|c|c|c|c|c|c|c|c|}
\hline \multirow{2}{*}{$\begin{array}{l}\text { Sector } \\
\text { Size of capital } 1 /\end{array}$} & \multicolumn{4}{|c|}{ All } & \multicolumn{4}{|c|}{ Manufacturing } & \multicolumn{4}{|c|}{ Nonmanufacturing } \\
\hline & All & Large & Medium & Small & All & Large & Medium & Small & All & Large & Medium & Small \\
\hline & & & & & & & & & & & & \\
\hline Fixed assets / Total assets & 54.8 & 62.0 & 47.2 & 48.0 & 51.0 & 55.7 & 43.1 & 42.9 & 56.4 & 66.4 & 48.8 & 49.4 \\
\hline Liquid liabilities / Total liabilities & 55.1 & 53.3 & 64.2 & 54.1 & 62.1 & 63.4 & 69.8 & 55.8 & 52.6 & 47.7 & 62.5 & 53.7 \\
\hline Total loans / Total liabilities & 29.5 & 22.2 & 30.0 & 38.7 & 21.8 & 15.7 & 25.1 & 36.1 & 33.0 & 26.8 & 31.9 & 39.3 \\
\hline Capital / Total assets & 6.7 & 9.6 & 4.0 & 3.8 & 7.9 & 10.4 & 3.9 & 3.5 & 6.1 & 9.1 & 4.0 & 3.9 \\
\hline Return on assets & 0.8 & 0.9 & 0.9 & 0.7 & 1.0 & 1.1 & 1.1 & 0.9 & 0.8 & 0.8 & 0.8 & 0.7 \\
\hline Interest cost & 1.9 & 1.9 & 1.8 & 2.0 & 1.8 & 1.7 & 1.8 & 2.0 & 1.9 & 2.0 & 1.8 & 2.0 \\
\hline Debt equity ratio & 222.1 & 168.2 & 278.9 & 307.3 & 138.6 & 114.9 & 177.2 & 208.1 & 288.9 & 230.4 & 342.5 & 348.2 \\
\hline Interest rate coverage (in times) & 1.0 & 0.9 & 1.0 & 1.0 & 1.0 & 1.2 & 1.0 & 1.0 & 1.0 & 0.9 & 1.0 & 1.0 \\
\hline Adjusted net profit margin $3 /$ & 3.3 & 6.2 & 1.6 & 1.5 & 4.4 & 6.6 & 1.9 & 1.4 & 3.0 & 6.0 & 1.6 & 1.6 \\
\hline Labor productivity $4 /$ & 0.3 & 0.8 & 0.3 & 0.2 & 0.4 & 0.4 & 0.4 & 0.2 & 0.3 & 0.8 & 0.3 & 0.2 \\
\hline
\end{tabular}

Sources: Ministry of Finance and staff estimates.

1 / by size of capital, which provides a proxy for firm size.

2/ Averages from 2000 by sector and size of capital.

$3 /$ Net profit margin adjusted by the capital ratio relative to its sectoral mean.

4/ Value-added per employee

\section{High leverage and tepid productivity growth among SMEs are closely linked to}

their weak profitability. Estimates based on data of nonfinancial corporate balance sheet from the Ministry of Finance suggest that a one-percentage point increase of debt-equity ratio generally reduces the adjusted net profit margin by about 0.2 percentage points (Table 5). Manufacturing firms and firms with large capital size have generally better profitability, while profitability for firms with smaller capital size is 1.2 percentage points (statistically significant) lower than larger firms, controlling for other factors. Robustness check using a vector error correction model (VECM) also illustrates the long-run net profit margin is affected by high leverage and weak productivity at the 5 percent significant level.

\section{However, these have not led to large-scale restructuring or exits of nonviable}

SMEs over the past decade. Overall, the firm turnover rate is only about one-third of that in 
the United Kingdom and the United States. In addition to country-specific factors, several market practices and guarantee programs could have limited incentives for banks and SMEs to restructure to improve performance (Appendix D).

Table 4. Japan: Performance and Soundness of SMEs

\begin{tabular}{lrrrrrr}
\hline & $\begin{array}{c}\text { Debt } \\
\text { equity } \\
\text { ratio 1/ }\end{array}$ & $\begin{array}{c}\text { Return on } \\
\text { assets 2/ }\end{array}$ & $\begin{array}{c}\text { Interest } \\
\text { coverage } \\
\text { ratio }\end{array}$ & $\begin{array}{c}\text { Borrowing } \\
\text { cost 2/ }\end{array}$ & Debt 3/ & $\begin{array}{r}\text { Repayment } \\
\text { capacity 4/ }\end{array}$ \\
\hline Full sample & 1.75 & 0.30 & 0.82 & 2.21 & 42079 & 0.09 \\
After 2008 & 1.28 & 0.14 & 0.44 & 2.06 & 42133 & 0.08 \\
Before 2008 & 1.98 & 0.38 & 0.93 & 2.29 & 42053 & 0.09 \\
Risk rating 5/ & & & & & & \\
1 & 1.24 & 3.57 & 8.39 & 1.79 & 12450 & 0.39 \\
2 & 1.99 & 1.59 & 3.01 & 1.97 & 24880 & 0.18 \\
3 & 2.56 & 0.92 & 1.76 & 2.06 & 34866 & 0.12 \\
4 & 2.93 & 0.57 & 1.19 & 2.02 & 37939 & 0.09 \\
5 & 2.72 & 0.31 & 0.83 & 2.00 & 37716 & 0.07 \\
6 & 2.28 & 0.15 & 0.53 & 2.09 & 40951 & 0.06 \\
7 & 1.70 & 0.07 & 0.31 & 2.23 & 47345 & 0.05 \\
8 & 0.64 & 0.03 & 0.19 & 2.41 & 56175 & 0.04 \\
9 & -1.32 & 0.00 & 0.09 & 2.65 & 67960 & 0.03 \\
10 & -1.74 & -1.85 & -0.30 & 2.99 & 89826 & 0.02 \\
\hline
\end{tabular}

Source: CRD.

$1 /$ Negative debt equity ratios and interest rate coverage indicates negative equity and net losses.

$2 /$ in percent.

$3 /$ in thousands of yen.

4/ Repayment capacity is defined as a ratio of the sum of net income and depreciation to debt level.

5 / Lower risk rating number indicates higher creditworthiness.

\section{These structural weaknesses and the survival of nonviable SMEs could impede} credit intermediation and growth potentials. Low profitability and high leverage among SMEs, particularly in nonmanufacturing sector, could have limited credit demand as those SMEs are more reluctant to invest (Steinberg and Ogawa 2009, Syed and Lee 2010). Continued survival of nonviable SMEs could weaken credit risk assessment in banks and reduce credit availability to startups and other viable firms once credit demand picks up (Arping, Loranth, and Morrison, 2010; Choe, 2006; Uesugi, 2010; and Uesugi and Sakai, 2005). Estimates from the Fund's GIMF model, addressing SME structural weaknesses, along with other structural reforms in the New Growth Strategies, could improve private investment through reducing banks' monitoring cost and enhancing firm productivity, which in turn would lift long-term growth relative to the baseline. Based on the Fund's GIMF model, addressing SME structural weaknesses could raise aggregate 
productivity by about $1 / 4$ percentage points, which in turn would lift long-term growth by 0.1 0.2 percentage points from the baseline. ${ }^{8}$

\section{Table 5. Japan: Regression Estimates on Corporate Adjusted Net Profit}

\begin{tabular}{|c|c|c|c|c|c|c|}
\hline \multicolumn{7}{|c|}{ Dependent variable: Adjusted net profit margin 1/ } \\
\hline \multirow{2}{*}{$\begin{array}{l}\text { Sample period } \\
\text { Specifications }\end{array}$} & \multicolumn{3}{|c|}{ Full sample (1960q1 to 2011 q3) } & \multicolumn{3}{|c|}{ Subsample (1980Q1 to 2011Q3) } \\
\hline & $(1)$ & $(2)$ & (3) & $(1)$ & (2) & (3) \\
\hline \multirow[t]{2}{*}{ constant } & 3.76 & 4.31 & 1.65 & 2.82 & 3.00 & -0.61 \\
\hline & $(0.36)$ & $(0.49)$ & $(0.60)$ & (0.39) & $(0.40)$ & $(0.42)$ \\
\hline \multirow[t]{2}{*}{ Lagged debt-equity ratio } & -0.26 & -0.24 & -0.27 & -0.15 & -0.14 & -0.20 \\
\hline & $(0.00)$ & $(0.00)$ & $(0.00)$ & $(0.00)$ & $(0.00)$ & $(0.00)$ \\
\hline \multirow[t]{2}{*}{ Lagged value-added per employee } & 1.60 & 1.47 & 1.43 & 3.31 & 3.25 & 3.16 \\
\hline & $(0.44)$ & $(0.45)$ & $(0.45)$ & $(0.47)$ & $(0.52)$ & $(0.46)$ \\
\hline \multirow[t]{2}{*}{ Lagged interest cost } & 0.05 & 0.04 & -0.02 & -0.14 & -0.14 & -0.24 \\
\hline & $(0.02)$ & $(0.02)$ & $(0.03)$ & $(0.02)$ & $(0.02)$ & $(0.03)$ \\
\hline \multirow[t]{2}{*}{ Lagged account receivables ratio 2/ } & & -0.05 & & & -0.01 & \\
\hline & & $(0.02)$ & & & $(0.03)$ & \\
\hline \multirow[t]{2}{*}{ Lagged current liabilities ratio } & & & 0.05 & & & 0.08 \\
\hline & & & $(0.01)$ & & & $(0.01)$ \\
\hline \multirow[t]{2}{*}{ Dummy - manufacturing } & 0.32 & 0.53 & 0.10 & 0.54 & 0.59 & -0.04 \\
\hline & $(0.15)$ & (0.19) & $(0.13)$ & $(0.15)$ & (0.19) & $(0.11)$ \\
\hline \multirow[t]{2}{*}{ Dummy - medium-sized } & -1.65 & -1.77 & -2.05 & -1.44 & -1.50 & -2.09 \\
\hline & $(0.21)$ & $(0.24)$ & $(0.26)$ & $(0.23)$ & $(0.10)$ & $(0.29)$ \\
\hline \multirow[t]{2}{*}{ Dummy - small-sized } & -1.73 & -1.75 & -2.01 & -1.17 & -1.19 & -1.39 \\
\hline & $(0.23)$ & $(0.24)$ & $(0.26)$ & $(0.27)$ & $(0.28)$ & $(0.20)$ \\
\hline Number of observations & 1026 & 1026 & 1026 & 762 & 762 & 762 \\
\hline F-statistics & 158.3 & 142.1 & 139.3 & 206.8 & 173.7 & 201.4 \\
\hline Adjusted R-squared & 0.54 & 0.54 & 0.55 & 0.69 & 0.69 & 0.72 \\
\hline
\end{tabular}

$1 /$ Net profit margin adjusted by the capital ratio relative to its sectoral mean.

2/ Account receivables to sales

3 / Numbers in parentheses are statistically significant at the 5 percent level.

\section{Market Practices on Collaterals and Risk-Based Financing}

\section{Banks' preference towards personal guarantees and fixed-asset collaterals in}

lending could impede smooth financing. Fixed assets (e.g., real estate) are common collaterals to secure business loans and banks' lending decisions also depend on availability of personal guarantees (Shirota, Imakubo, and Nishioka 2011) (Figure 9). According to METI's survey, over a quarter of responding SMEs consider the use of personal guarantee improves trust with and ease credit from banks but at the same time place obstacles to

\footnotetext{
${ }^{8}$ The GIMF model is a multi-region dynamic general equilibrium model that analyzes the growth impact of an increase in productivity. We calibrate the aggregate increase in productivity from the corporate balance sheet data (Table 1). Large firms are about twice and four times productive than SMEs in manufacturing and nonmanufacturing sectors, respectively. The manufacturing sector accounts for about one-third of total production. If SME structural weaknesses were addressed, we expect the productivity would increase to the level about 80 percent of that among large firms. As a result, the aggregate productivity would increase by $1 / 4$ percentage points.
} 
business transfers. Efforts were taken by SMRJ, CGC, JFC in promoting asset-based lending (ABL). The BoJ also established a new credit facility (as much as $¥ 1 / 2$ trillion) to support riskbased lending that allow for the use of business-to-business credits as collateral to smooth financing. However, many financial institutions consider the ABL is not well established and difficulties in assessing the fair value of assets have limited its use. ${ }^{9}$

\section{Figure 9. Japan: Market Practices and Institutional Features of Credit Intermediation}

Collaterals and personal guarantees are common in lending relationship among SMEs.

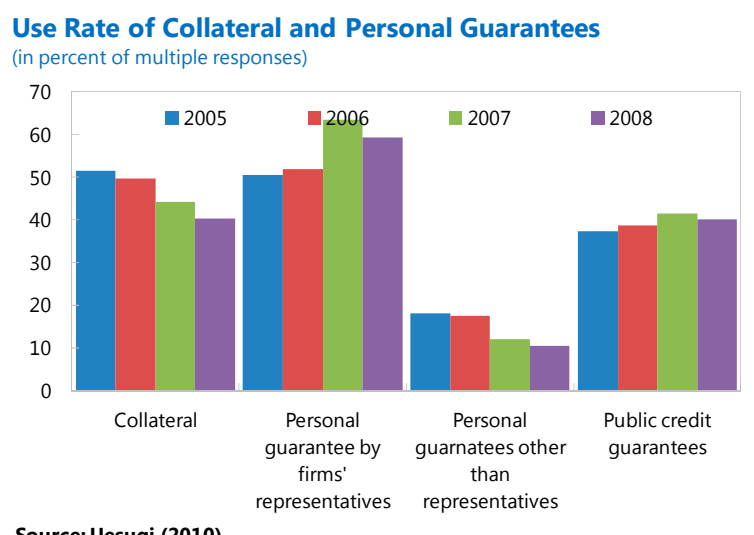

Other financing means, such as $A B L$, are not very well established or not considered to be introduced...

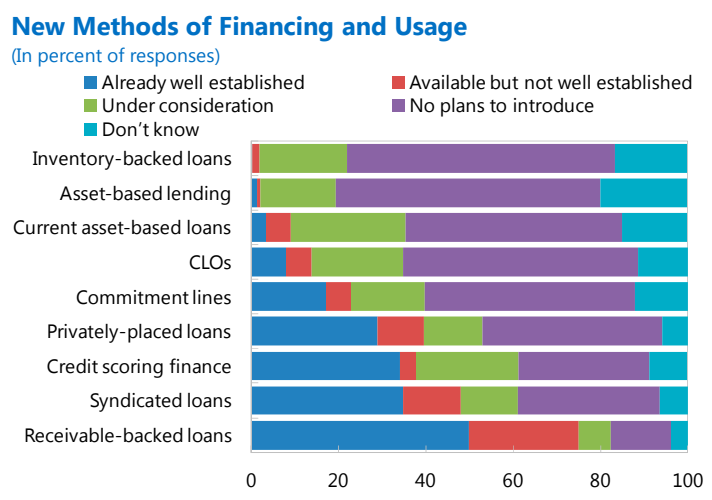

Source: Japan Small Business Research Institute (2006)
Personal guarantees help building trust with banks and ease financing but could pose difficulties in business transfers.

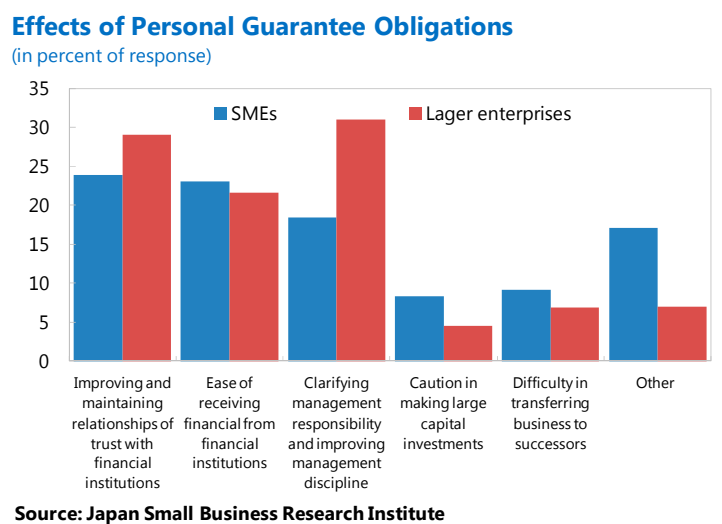

Start-ups rely predominantly on self-finance, and venture capital funds are uncommon, despite large funding they could raise.

Sources of startup funds (In percent except as noted)

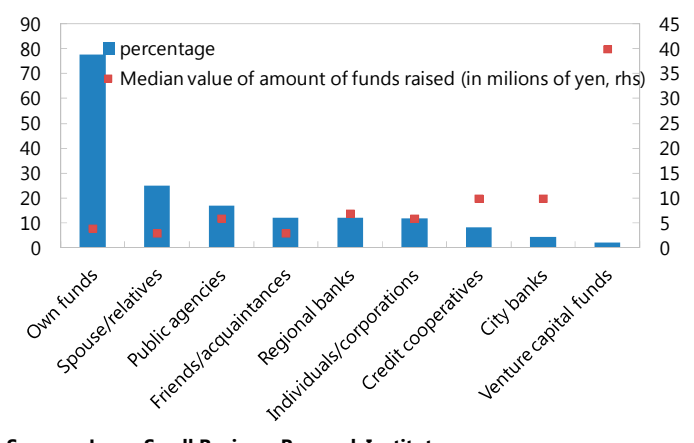

Sources: Japan Small Business Research Institute

\footnotetext{
${ }^{9}$ Banks may not have capacity and expertise to evaluate prospects based on future cash flows of innovative SMEs and typically require real-estate for secured loans (JSBRI 2011).
} 
Figure 9. Japan: Market Practices and Institutional Features of Credit Intermediation (cont'd)
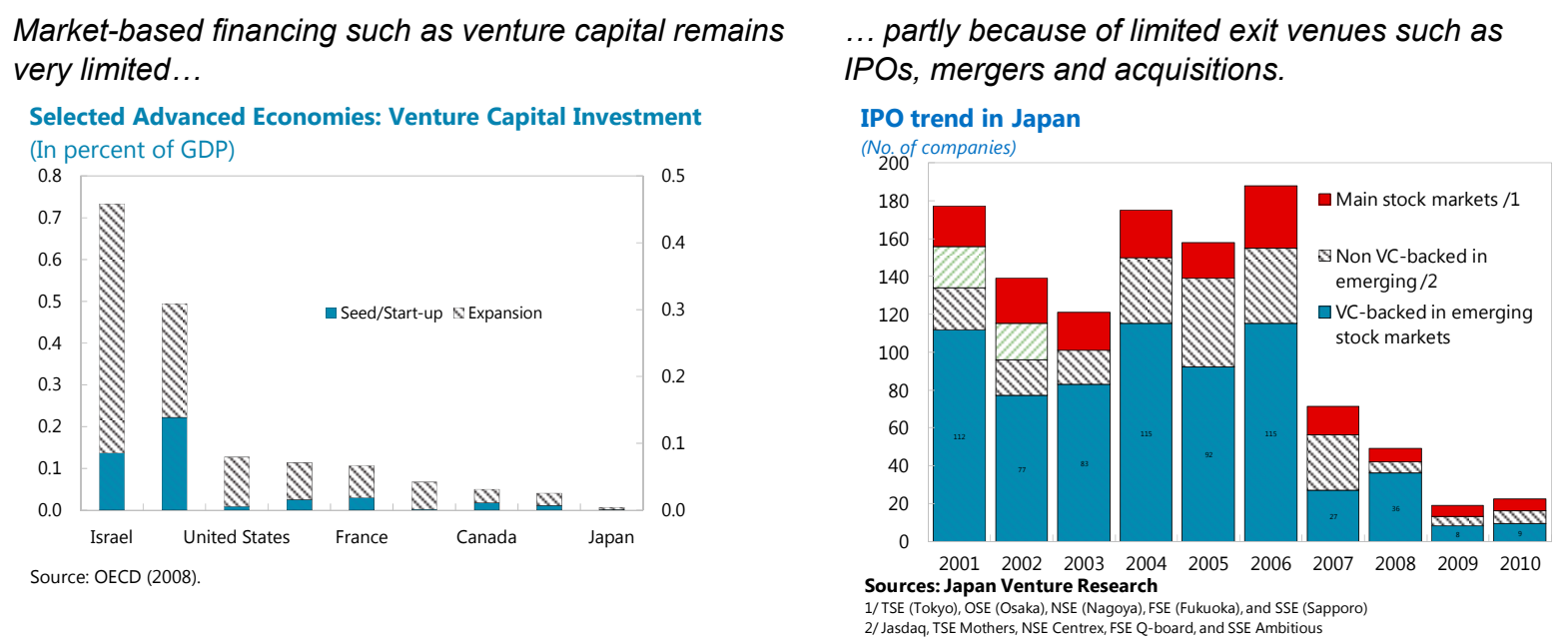

26. In that regard, electronic registration on claims to facilitate financing is at the early stage of development. ${ }^{10}$ The electronic registration under the Electronically Recorded Monetary Claims (ERMC) helps stipulate rights on claims, saves custody cost for pledged bills/notes, and avoids the risk of double assignment on claims. The system could uplift significantly banks' financing by reforming the lending operations to SMEs and expanding as a settlement facility and securitization of syndicated loans. However, the development is still at an early stage and banks need to entail a sizeable investment and operating costs (e.g., converting receivables to electronic claims) (Miyakawa, 2009).

\section{Credit availability for risk-based capital appears to be limited despite abundant}

liquidity. Loans tend to rely on real estate collateral and personal guarantees, and often little consideration is given to future cash flows from business. Growth companies that have large potentials and intellectual property but lack real estate assets are often unable to access adequate financing. Securitization of SME loans is not common given low interest rates and difficulties on transferring personal guarantees. In addition, Japan ranks second to last in venture capital investment as a share of GDP among OECD and has low business transfers and declining initial public offering. Start-ups rely predominantly on self-finance (from personal savings and borrowings from families), which tend to raise only a limited amount of funds (Figure 9). ${ }^{11}$ Risk-based capital is limited partly due to inadequate exit venues such as IPOs and mergers and acquisitions, although these financing options are able to raise sizeable

\footnotetext{
${ }^{10}$ The FSA and Ministry of Justice have enacted an electronic registration in December 2008 (Act on Electronically Recorded Monetary Claims, ERMC) and several recording institutions' registries were established.

${ }^{11}$ Efforts were taken to support startups by the SME Agency (http://www.chusho.meti.go.jp/pamflet/leaflet/l2011/03-venture.pdf).
} 
funds and offer expertise and know-how for business operations (Chemmanur, Krishnan, and Nandy, 2010).

\section{Financial Position of Regional and Shinkin Banks}

\section{Weak financial position in regional and shinkin banks could pose constraints on} credit risk assessment. Asset quality of regional and shinkin banks have improved over the past decade but deteriorated during the financial crisis with the nonperforming loans (NPL) ratio rose to over 3 and 6 percent for regional and shinkin banks, respectively. The NPLs could be understated under the measure of relaxation of loan classification requirements. Preliminary estimates show that about 17-32 percent of credit in regional and shinkin banks are with guarantees, relative to 4 percent in city banks (Table 5). While the credit channels function smoothly in these banks, their weak financial positions might not have sufficient incentives to restructure nonviable SME loans as recognizing restructuring losses could lead to a further deterioration of NPLs and profits, which could tighten financing conditions as temporary measures are gradually phased out.

\begin{tabular}{|c|c|c|c|c|}
\hline (in trillions of yen) & $\begin{array}{c}\text { Outstanding } \\
\text { amount }\end{array}$ & $\begin{array}{l}\text { Share (in } \\
\text { perecnt) }\end{array}$ & $\begin{array}{c}\text { Estimated } \\
\text { outstanding } \\
\text { guarantees } \\
\end{array}$ & $\begin{array}{l}\text { Share of credit with } \\
\text { guarantees (in } \\
\text { percent) }\end{array}$ \\
\hline Private banks & 229.1 & 90.4 & 35.1 & 15.3 \\
\hline City banks & 78.3 & 30.9 & 2.9 & 3.7 \\
\hline Regional banks & 66.1 & 26.1 & 11.2 & 17.0 \\
\hline Regional banks tier 2 & 23.5 & 9.3 & 5.0 & 21.3 \\
\hline Trust bank and long-term credit banks & 10.6 & 4.2 & 0.4 & 3.7 \\
\hline Credit associations & 41.3 & 16.3 & 13.2 & 32.0 \\
\hline Credit cooperatives & 9.3 & 3.7 & 2.3 & 24.9 \\
\hline with credit guarantees $1 /$ & 35.1 & 13.8 & & \\
\hline Other money lenders & 2.9 & 1.1 & n.a. & n.a. \\
\hline Government financial institutions (GFIs) & 21.4 & 8.4 & n.a. & n.a. \\
\hline Total & 253.4 & 100.0 & 35.1 & \\
\hline
\end{tabular}

Source: SME Agency, Morgan Stanley Research, and staff estimates.

1/ From national credit guarantee corporation as of end-FY2010.

29. Regional and shinkin banks are focusing towards relationship-based banking. Besides extending credit, many regional and shinkin banks also have transactional and advisory relations with their clients to support their business needs. Focusing on long-term relations with clients could reduce monitoring costs, enable banks to resolve borrowers' difficulties in the early stage, and provide support over the long term, which could bolster profits. Further efforts to enhance relationship-based banking are necessary as many loan contracts still require traditional collaterals and bank profitability remains sluggish.

30. Some regional and shinkin banks have inevitably strong ties with local SMEs and local governments given their presence on local regions. While there are benefits for 
stronger relationship-based practices, banks with proprietary information on high-risk firms could exploit such an advantage by substituting nonguaranteed loans for guaranteed loans, thereby transferring credit risks (Choe, 2006; Ono, 2011). Moreover, according to the Financial System Report (Bank of Japan, April 2012), firms with strong capital ties to banks rarely outperformed in terms of profitability, while posing higher credit concentration risks.

\section{E. Institutional and Regulatory Factors}

31. Several institutional and regulatory factors could have discouraged private investment and startups, possibly weakening credit demand, although they do not appear to impede directly credit channels at present.

- $\quad$ Regulations on starting business - Starting business is more difficult in Japan relative to other G7 countries and industrialized Asian economies, particularly in terms of duration and costs, despite overall eased financing conditions (Figure 10). 


\section{Figure 10. Japan: Firm Dynamics and Regulatory Factors}

Starting a business is difficult due to regulatory issues, which could limit incentives for investment.

\begin{tabular}{lrcc}
\hline \multicolumn{1}{c}{ Economy } & Japan & $\begin{array}{c}\text { G-7 average } \\
\text { excl. Japan }\end{array}$ & $\begin{array}{c}\text { Selected Asian } \\
\text { economies 1/ }\end{array}$ \\
\hline Ease of Doing Business Rank & 20 & 27 & 7 \\
Starting a Business - Rank & 107 & 39 & 9 \\
Getting Credit - Rank & 24 & 33 & 7 \\
Protecting Investors - Rank & 17 & 44 & 37 \\
Enforcing Contracts - Rank & 34 & 43 & 9 \\
Resolving Insolvency - Rank & 1 & 23 & 12 \\
\hline
\end{tabular}

Source: World Bank (2012).

1/ include Australia, Hong Kong, SAR, Korea, and Sinagpore

Firm dynamics are lackluster, as firms' entry rates...

\section{International comparison of entry rates}

(In percent)

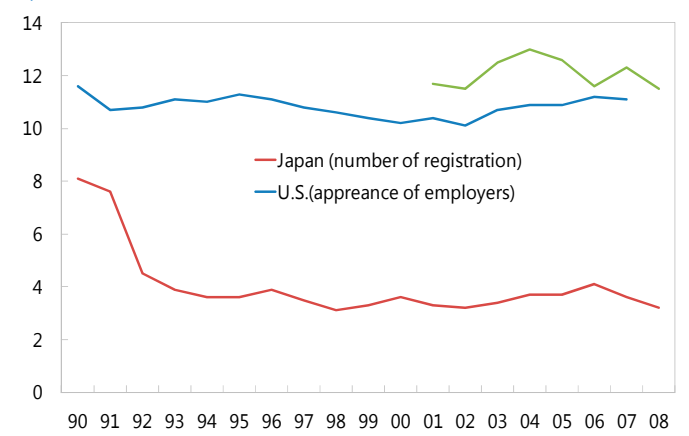

Sources: 2011 White paper on Small and Medium Enterprises in Japan, JSBRI

... possibly hindered by information availability and personal guarantees.

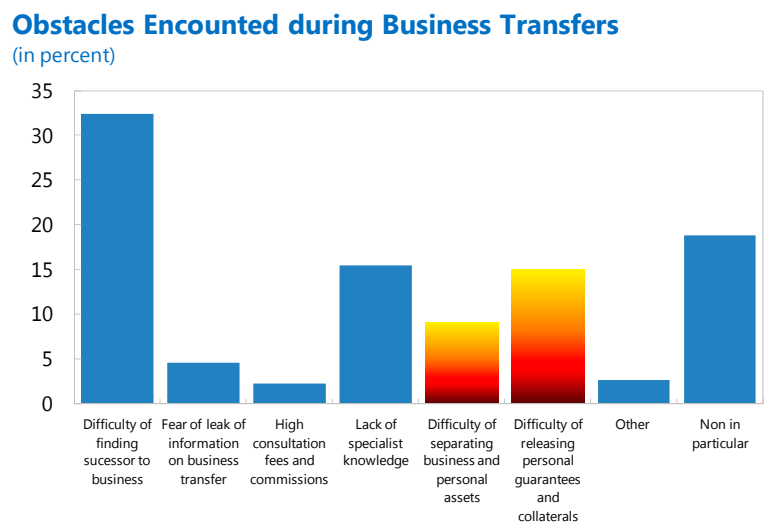

Source: Japan Small Business Research Institute
Business transfer rate has been low and declined recently.

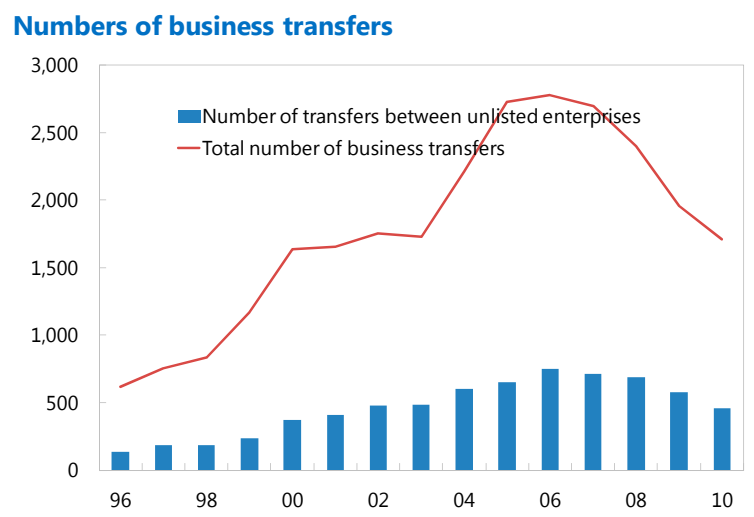

Sources: Japan Small Business Research Institute

... and exit rates are much lower than other advanced countries.

International comparison of exit rates (In percent)

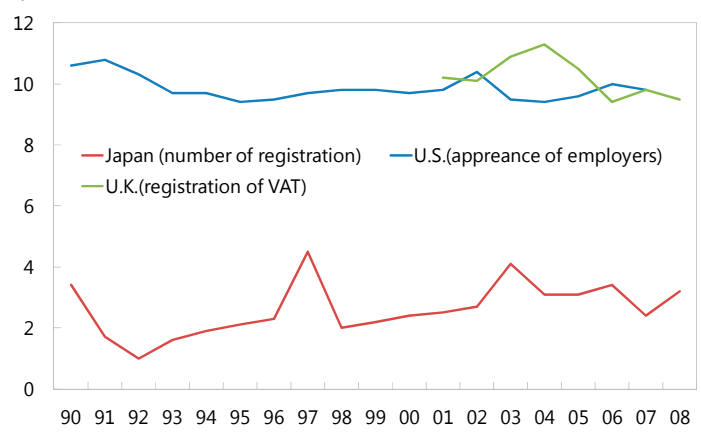

Sources: 2011 White paper on Small and Medium Enterprises in Japan, JSBRI

Pension funds are risk-averse and seldom invest in private equity or venture capital funds that could generate higher returns and promote startups.

Asset allocation of Public Pension Reserve Fund (In percent of total investment 2006)

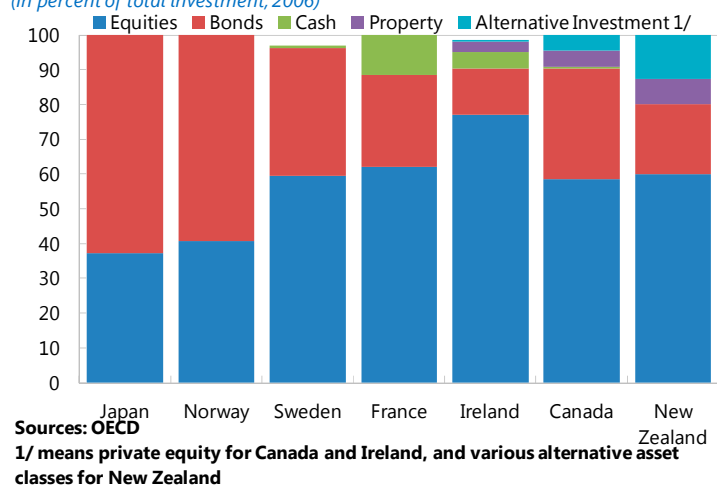


- Credit information availability - Several credit registries, including CRD, RDB, CRITS, and SDB, were established in 2000s to facilitate credit information but survey results suggest that over half of respondents consider information availability remains a challenge in assessing SME credit risks and business transfer (e.g., limited information disclosure, and timely information not provided). This likely contributes to a financing gap for the 'middle-risk' group and inactive private credit insurance practices (Schaede, 2005). ${ }^{12}$

- Investment of long-term institutional investors - A large share of the assets of public pensions are invested in JGBs. Allocating a small fraction of assets towards alternative and less conservative investment strategies such as venture capital and private equity could improve long-term rate of return and contribute to channeling funds towards private sector investment, eventually lifting growth (Figure 10). ${ }^{13}$

\section{IMPROVING EFFICIENCY OF CREDIT CHANNELS}

\section{Financial sector policies should aim to address the potential bottlenecks in credit} channels. Several selected support measures need to be better targeted or phased out in a timely manner to provide a more enabling environment as credit demand revives.

- $\quad$ Temporary support measures, notably the SME Financing Facilitation Act, should be set to expire as scheduled by March 2013 to mitigate costs that are likely to exceed benefits.

- $\quad$ Terms of credit guarantees would need to be tightened in several dimensions.

Special and counter-cyclical credit guarantees of up to 100 percent of loan value need to be phased out gradually as the recovery takes hold, taking into account the previous experience in 2000-01 in withdrawing special guarantees that led to a marked rise of bankruptcies. Over time, reducing the normal guarantee coverage ratio to about 60 percent - in line with international averages (IMF, 2006) —would ensure market discipline and encouraging banks to step up monitoring credit risks (Leuth, Steinberg, and Syed, 2009). In that context, a step-wise approach appears more appropriate to limit negative costs such as a rapid tightening of financing conditions.

\footnotetext{
${ }^{12}$ Credit registries in Japan include Credit Risk Database (CRD), Risk Data Bank of Japan (RDB), Credit Risk Information Total Services (CRITS), and shinkin data bank (SDB). Financial institutions could also get access to credit risk databases from designated credit bureaus based on the Financial Instruments and Exchange Act, such as Japan Credit Information Reference Center Corp (JICC) and Credit Information Center (CIC). There appears no centralized credit bureau on consumer loans (banks and consumer finance companies have their own records), leaving scope for improving efficiency through information sharing.

${ }^{13}$ The FSA amended related Cabinet Office Ordinance in 2010, to add new stock subscription rights and loans, including subordinated loans, as a means of providing funds by specialized investment subsidiaries of banks and insurance companies, which could contribute to an expansion of investment and loans for venture companies and companies under business revitalization.
} 
Possibilities of rollovering guarantees would need to be scrutinized and the guarantee fee could be set to rise over the usage period to release resources for other firms in needs.

- $\quad$ Direct financial support should be better targeted such as redirecting GFI funds toward start-ups and high growth areas. Empirical studies find that startups obtaining financing from GFIs in Japan tend to have better performance throughout their beginning phrase (Fukanuma, and Tadanobu, and Watanabe 2006). Policy could encourage an increasing use of market-based approach such as public-private partnership (PPP).

\section{Efforts should be taken to advance GFIs reform and ensure level-playing fields} with private counterparts. Momentum for full privatization plans of many GFIs (including Japan Post) need to be advanced to enhance accountability and reduce uncertainty that could hinder GFIs' business planning (Appendix C). In the interim, a more transparent and accountable governance for GFIs is needed to limit contingent fiscal risks. Further efforts should ensure consistent treatments on taxation, accounting, interest setting, and regulatory requirements, taking into account differences in mandate and funding structure of GFIs. Supervision of GFIs could be strengthened through streamlining ministerial responsibilities and more frequent inspections by the FSA.

\section{Structural weakness in SMEs would need to be addressed through accelerating} restructuring (Appendix D), which would encourage exits of nonviable firms and new startups. Wider use of debt-equity swap and pre-packs would incentivize banks and SMEs to restructure (Laryea 2010) under out-of-court voluntary workouts. Considerations could be given towards establishing an asset management company (AMC) tailored to SMEs to jumpstart the process. For in-court restructuring, use of debtor-in-possession could mitigate an erosion of firm value during bankruptcy procedures.

\section{Policies could facilitate financing by encouraging wider use of electronic} registration on claims and risk-based financing. Efforts should continue to encourage a shift from fixed asset collaterals and personal guarantees towards asset-based lending among financial institutions. A broader use of electronic registration systems under the ERMC should be pursued. For instance, the authorities (government and municipalities) and large corporations could take the lead in utilizing electronic claims to promote an increasing origination and trading of electronic claims. Moreover, a more diverse set of market-based financing — such as securitization of SME loans and venture capital—beyond bank loans would suit better the needs of firms in various development stages (Financial System Council, 2009).

36. As temporary support measures are gradually phased out, strengthening financial positions of regional and shinkin banks would prevent a tightening of financing conditions. Although these banking segments channel credit smoothly at present, several measures could improve their resilience and avoid a tightening of financing conditions when temporary support measures expire. 
- Banks could upgrade their risk management capacity to reflect underlying credit risks. At the same time, banks need to reduce their credit and market risk exposures and diversify their client bases to improve their financial positions. Policies could focus on further advancing benefits from relationship-based banking while monitoring drawbacks of close linkages between banks and SMEs.

- From a broad perspective, a gradual consolidation of regional and shinkin banks based on private business decisions could improve core profitability in the long run, and strengthen their resilience against shocks (Hosono, Sakai and Tsuru 2006; and Jones and Tsutsumi, 2009). Gradual consolidation could also mitigate negative consequences from close ties with SMEs and local governments, thereby encouraging SME restructuring. Supervision on these banks should be strengthened to account for the impact when temporary measures are withdrawn.

37. Several regulatory measures should be revised to improve credit intermediation and stimulate private investment.

- $\quad$ Regulations should be streamlined to reduce the duration and cost of starting businesses, which could promote business creation and transfers.

- $\quad$ Long-term institutional investors such as pension funds could be encouraged to provide risk-based capital to facilitate startups and improve investment returns.

- Consideration could be given to broaden the coverage of credit registries through a more centralized database, and incorporate consumer data bureau covering household or personal credit information. 


\section{REFERENCES}

Arping, S., Loranth G., and Morrison A. (2010) 'Public initiatives to support entrepreneurs: Credit guarantees versus co-financing', Journal of Financial Stability, 6(2010), pp. 26-35.

Bank of Japan (2011) 'Financial System Report', October 2011.

Chemmanur T., Krishnan K., and Nandy D. (2010) 'How does Venture Capital Financing Improving Efficiency in Private Firms? A Look Beneath the Surface', 2010

Choe, C. (2006) “ The Political Economy of SME Financing and Japan's Regional Bank Problems', Working Paper 2006, University of New South Wales.

Desai, M., Foley, C., and Hines J.R. (2004) 'A Multinational Perspective on Capital Structure Choice and Internal Capital Markets,' Journal of Finance (59) no.6, December 2004, p.2451-2488.

Fukuda, A. and Hiorta S. (1996) 'Main Bank Relationships and Capital Structure in Japan,' Journal of the Japanese and International Economies, vol. 10(3), pp. 250-261, September 1996

Fukanuma, H., and N. Tadanobu, W. Watanabe (2006) 'Do Governmental Financial Institutions Help Startups Grow? Evidence from Japan’, Keio University Working Paper, November 2006.

Gul, F. (1999) 'Growth Opportunities, Capital Structure and Dividend Policies in Japan', Journal of Corporate Finance, 1999

Hasegawa and Lam (2011) 'Aging in Japan and Household Asset Allocation', mimeo, available upon request.

Hirota, S. (1999) 'Are Corporate Financing Decisions Different in Japan? An Empirical Study on Capital Structure', Journal of the Japanese and International Economies, 1999

Hosono K., Sakai K., and Tsuru K.(2006) 'Consolidation of Cooperative Banks (Shinkin) in Japan: Causes and Consequences’, 2006

International Monetary Fund (2006) 'Republic of Korea: Selected Issues’, October 2006.

International Monetary Fund (2011) 'Japan: Article IV Consultation Staff Report', July 2011.

International Monetary Fund (2012) 'World Economic Outlook', April 2012.

Japan Financial System Council (2009) 'Overview of the Medium-term Vision for the Future of the Japanese Financial system’, February 2009

Japan Small Business Research Institute (2011) 'White Paper on Small and Medium-sized Enterprises in Japan', 2011.

Koo R. and Sasaki M. (2010) 'Japan’s disposal of bad loans: failure or success,' Nomura Research Institute, 2010

Korajczyka R.A. and Levy A. (2003) 'Capital Structure Choice: Macroeconomic Conditions and Financial Constraints, Journal of Financial Economics, 2003. 
Laryea T. (2010) 'Approaches to Corporate Debt Restructuring in the Wake of Financial Crises', International Monetary Fund Staff Position Note, January 2010. www.imf.org/external/pubs/ft/spn/2010/spn1002.pdf

Leuth, E., Steinberg C., and Syed M. (2009) 'Exit from SME Support Measures', Asia and Pacific Regional Economic Outlook, October 2009.

Ministry of Economy, Trade, and Industry (2006) 'The ABL (Asset Based Lending) Workshop press release', 2006

Miyakawa, H. (2009) 'Electronic Claims' Potential to Revolutionize Finance', Nomura Research Institute, Lakyara vol.58, August 2009.

OECD (2006) 'Financing SMEs and Entrepreneurs', Policy Brief, November 2006.

Jones, R. and Tsutsumi M. (2009) 'Financial Stability: Ovecoming the Crisis and Improving the Efficiency of the Banking Sector in Japan', OECD Economics Department Working Papers No.738, December 2009.

OECD (2010), 'The Assessment of Government Support Programs for SMEs and Entrepreneurs' Access to Finance in the Global Crisis', OECD Center for Entrepreneurships, SMEs, and Local Development (WPSMEE), Final Synthesis Report, November 2010

Ono, A., Sakai, K., and Uesugi, I. (2008) 'The Effects of Collateral on SME Performance in Japan', RIETI Discussion Paper Series 08-E-037, 2008

Ono, A., Uesugi, I., Yasuda, Y. (2011) 'Are lending relationships beneficial or harmful for public credit guarantees? Evidence from Japan's emergency credit guarantee program,' RIETI Discussion Paper Series, 11-E-035, March 2011

Rajan, R. (1994) 'What do we Know about Capital Structure? Some Evidence from International Data,' NBER Working Paper 1994

Sato T. (2008) 'Japan Economics: Towards Credit Crunch Relief,” Morgan Stanley Economic Research, Japan, September 2008

Schaede U. (2005) 'The "Middle Risk Gap" and Financial System Reform: Small Firm Financing in Japan, Monetary and Economic Studies, February 2005

Shirota, T., Imakubo, K., and Nishioka, S. (2011) "Issues surrounding the financing of small and medium enterprises - Liquidation of receivables through asset-based lending and electronically recorded monetary claims” Bank of Japan Review, June 2011 (in Japanese).

Steinberg, C. and S. Ogawa (2009), “Current Challenges Facing SMEs in Japan,” in Japan: Selected Issues, July 2009, Country Report No. 09/211.

Syed, M. and J. Lee (2010) 'Raising Medium-Term Growth: What Role Can Investment Play?' International Monetary Fund Country Report Report No. 10/212, July 2010.

Tokuda, H. (2011) 'Searching for clues to the low profitability and competitiveness of Japanese SMEs: an analysis based upon international comparisons', Mizuho research Institute, research Paper No.28, May 2011.

World Bank Group (2010) 'State Financial Institutions', Financial and Private Sector Development Vice Presidency, Note No.12, January 2010. 
World Bank Group (2011) 'Doing Business 2012: Doing Business in a More Transparent World', 2011

Udell, G. (2006) 'SME Financing: A Global Perspective,' Indiana University Working Paper, 2006

Uesugi I. (2010) 'The impact of international financial crises on SMEs: The case of Japan', Hitotsubashi University Working Paper, 2010

Uesugi, I. (2008) 'Efficiency of Credit Allocation and Effectiveness of Government Credit Guarantees: Evidence from Japanese Small Businesses', Bank of Japan Working Paper Series, No.08-E-2, February 2008.

Uesugi, I., Sakai, K.(2005) ‘The Special Credit Guarantee Program in Japan’, mimeo.

Uesugi, I., Sakai, K., and Yamashiro G. (2010) 'The Effectiveness of Public Credit Guarantees in the Japanese Loan Market', January 2010, Journal of Japanese and International Economy

Uesugi, I., K. Sakai, and Watanabe, T (2005) 'Firm Age and the Evolution of Borrowing Costs: Evidence from Japanese Small Firms, 2005

Yamashita Y. and T. Sakiyama, (2011) 'Profits of Japanese Banks and Market ValuationsComparison between Net Income and Comprehensive Income’, Bank of Japan Review, 2011 E-5, October 2011.

Yasuyuki F. (2007) 'Japan’s Loans are Changing- Are its Banks?', Nomura Capital Market Review Vol. 10, No.2., 2007 


\section{APPENDIX I-REgRESSION ANALYSIS ON HOUSEHOLD Portfolio Allocation ACross Age ANd COHORTs ${ }^{14}$}

\section{A. Data}

\section{Data is based on 'Household Savings Survey' conducted by Postal Office}

Research Institute. The survey covers more than 3,000 households the sample period of 1988-2004 in a bi-annual basis. Each survey covers about 3,000-5,000 households, with a total of 36,217 observations. Survey data include the amount of each type of financial assets held by households at the observation years, and household characteristics, including (a) the age of household heads, (b) annual income, (c) household head's educational level, (d) household size, and (e) geographical locations of household. Observations without household characteristics are excluded. This reduces the sample size to 24,593 .

\section{B. Methodology}

The baseline regression (R1) takes the following form.

$$
y_{i, j, t}=b_{0}+\boldsymbol{b}_{\boldsymbol{i}} \boldsymbol{D}_{\boldsymbol{i}}+\boldsymbol{b}_{\boldsymbol{j}} \boldsymbol{D}_{\boldsymbol{j}}+\boldsymbol{b}_{\boldsymbol{t}} \boldsymbol{D}_{\boldsymbol{t}}+\boldsymbol{\beta}_{\boldsymbol{t}} \boldsymbol{H}_{\boldsymbol{i}, \boldsymbol{j}, \boldsymbol{t}}+e_{i, j, t} \quad(i=\text { age, } j=\text { cohort, } t=\text { time })
$$

39. Variable $y$ refers to the dependent variable, which varies according to the type of financial assets under consideration. The analysis includes deposits, stocks and investment trust, and life insurance, which is expressed as ratios to total financial assets. A censored-type regression (Tobit model) is applied on each dependent variable. Dummy variables are assigned for age, cohort, and time as follows:

- $\boldsymbol{D}_{\boldsymbol{i}}$ is the age group (10 years) dummies, separated into age groups under $30,30 \mathrm{~s}, 40 \mathrm{~s}$, $50 \mathrm{~s}$ and over 70 . The age group of $60 \mathrm{~s}$ will be the base;

- $\quad \boldsymbol{D}_{\boldsymbol{j}}$ is the cohort group (10-year cohort) dummies, separated into cohort group with birth-years 1900-09, 1910-19, 1920-29, 1930-39, 1945-49, 1950-59, 1960-69, 197074, 1975-84. The pre-WWII cohort 1940-44 will be the base; and

- $\quad \boldsymbol{D}_{\boldsymbol{t}}$ is the time dummies, separated for each survey 1988, 1990, 1992, 1994, 1996, 1998, 2000 and 2002. Year 2004 will the base.

- $\quad \boldsymbol{H}_{i, j, t}$ is a set of control variables for households including income level, education level, geographical location, and size of the households.

Two additional sets of regression are performed. The second regression (R2) introduces additional household characteristics to the baseline regression using dummy variables, including household annual income, household size, education (1 if household head holds a university degree; 0 otherwise), and city size dummies ( 6 broad categories; 0 if household living in noncity areas). Instead of year dummies, the third regression (R3) includes market

\footnotetext{
${ }^{14}$ This part incorporates the analysis from Hasegawa and Lam (2011) on the study of household financial asset allocation.
} 
condition variables such as real deposit rates, excess return of stocks over deposits, and stock market volatility.

\section{Results}

40. While households in aggregate holds more than half of financial assets as deposits, the proportion appears to vary across age- decreases at first but increases as households get older, bottoming at age around 30s to 40s (coefficients on age dummies are statistical significant at 5 percent level). Across regressions, the deposit ratio decreases for age under 30 to $30 \mathrm{~s}$ but increases from $50 \mathrm{~s}$ to over $70 \mathrm{~s}$, consistent with the fact that larger proportion of financial assets is held as deposits over age in Japan.

41. Cohort difference exists in asset allocation. Households born after 1970considered as 'post-bubble generations' - tend to allocate more in deposits and less in risky investments (stocks and investment trust) than former cohorts. A possible explanation could be related to households experiencing asset bubbles at younger age would become more risk averse than those who have stable returns on risky assets. It could also be driven by declining wage growth expectation over cohorts. Risk appetite for younger cohorts may be less as it is more difficult to recover losses on asset holdings through wage income.

42. Coefficients on the real deposit rate are positive for deposit ratios but negative for the proportion of equities and investment trusts, both statistically significant at 5 percent level. This would provide evidence that households respond to real returns through reallocation of financial assets.

43. Coefficients on household characteristics suggest that households living in larger cities or with higher education tend to allocate more in risky assets and less on deposits, perhaps with better access to various investment options or better understanding of riskreturn tradeoff. 
Appendix Table 1. Regression Estimates on Household Assets Allocation

\begin{tabular}{|c|c|c|c|c|c|c|c|c|c|}
\hline \multirow[t]{2}{*}{ Dependent Variable } & \multicolumn{3}{|c|}{ Deposits / Total Financial Assets } & \multicolumn{3}{|c|}{ Stocks + Investment Trusts / Total Financial Assets } & \multicolumn{3}{|c|}{ Life Insurances / Total Financial Assets } \\
\hline & (1) & (2) & (3) & (1) & (2) & (3) & (1) & (2) & (3) \\
\hline Sample Period & $1988-2004$ & $1988-2004$ & $1988-2004$ & $1988-2004$ & $1988-2004$ & $1988-2004$ & $\begin{array}{c}1988-2004 \\
\text { (excludes 1998) }\end{array}$ & $\begin{array}{c}\text { 1988-2004 } \\
\text { (excludes 1998) }\end{array}$ & $\begin{array}{c}1988-2004 \\
\text { (excludes 1998) }\end{array}$ \\
\hline Age Dummies & & & & & & & & & \\
\hline Dage under 30 & 0.067 & 0.055 & -0.146 & -0.097 & -0.111 & -0.13 & -0.039 & -0.018 & 0.123 \\
\hline & {$[0.03]^{* *}$} & {$[0.03]^{*}$} & {$[0.03]^{* * *}$} & {$[0.05]^{* *}$} & {$[0.05]^{* *}$} & {$[0.04]^{* * *}$} & {$[0.03]$} & [0.03] & {$[0.03]^{* * *}$} \\
\hline Dage 30s & -0.052 & -0.037 & -0.17 & 0.01 & -0.024 & -0.025 & 0.019 & 0.015 & 0.109 \\
\hline & {$[0.02]^{* *}$} & {$[0.02]$} & {$[0.02]^{* * *}$} & {$[0.03]$} & {$[0.03]$} & {$[0.03]$} & [0.02] & [0.02] & {$[0.02]^{* * *}$} \\
\hline Dage 40s & -0.075 & -0.051 & -0.142 & -0.005 & -0.033 & -0.036 & 0.06 & 0.038 & 0.102 \\
\hline & {$[0.02]^{* * *}$} & {$[0.02]^{* * *}$} & {$[0.02]^{* * *}$} & [0.03] & {$[0.03]$} & {$[0.02]$} & {$[0.02]^{* * *}$} & {$[0.02]^{* *}$} & {$[0.02]^{* * *}$} \\
\hline Dage 50s & -0.063 & -0.044 & -0.091 & 0.006 & -0.02 & -0.025 & 0.048 & 0.033 & 0.066 \\
\hline & {$[0.01]^{* * *}$} & {$[0.01]^{* * *}$} & {$[0.01]^{* * *}$} & {$[0.02]$} & {$[0.02]$} & {$[0.02]$} & {$[0.01]^{* * *}$} & {$[0.01]^{* * *}$} & {$[0.01]^{* * *}$} \\
\hline Dage over 70 & 0.071 & 0.059 & 0.108 & -0.012 & 0.002 & 0.012 & -0.059 & -0.05 & -0.082 \\
\hline & {$[0.01]^{* * *}$} & {$[0.01]^{* * *}$} & {$[0.01]^{* * *}$} & {$[0.02]$} & {$[0.02]$} & {$[0.02]$} & {$[0.01]^{* * *}$} & {$[0.01]^{* * *}$} & {$[0.01]^{* * *}$} \\
\hline Cohort Dummies & & & & & & & & & \\
\hline Dcohort 1900_09 & 0.256 & 0.256 & 0.142 & -0.082 & -0.069 & -0.039 & -0.285 & -0.295 & -0.21 \\
\hline & {$[0.07]^{* * *}$} & {$[0.07]^{* * *}$} & {$[0.07]^{*}$} & {$[0.11]$} & {$[0.10]$} & {$[0.10]$} & {$[0.08]^{* * *}$} & {$[0.08]^{* * *}$} & {$[0.08]^{* *}$} \\
\hline Dcohort 1910_19 & 0.034 & 0.033 & -0.083 & -0.002 & 0.018 & 0.014 & -0.055 & -0.062 & 0.015 \\
\hline & {$[0.03]$} & {$[0.03]$} & {$[0.03]^{* * *}$} & {$[0.04]$} & {$[0.04]$} & {$[0.04]$} & {$[0.03]^{*}$} & {$[0.03]^{*}$} & {$[0.03]$} \\
\hline Dcohort 1920_29 & 0.021 & 0.014 & -0.069 & 0.016 & 0.036 & 0.029 & -0.032 & -0.032 & 0.027 \\
\hline & {$[0.02]$} & {$[0.02]$} & {$[0.02]^{* * *}$} & {$[0.02]$} & {$[0.02]$} & {$[0.02]$} & {$[0.02]^{*}$} & {$[0.02]^{*}$} & {$[0.02]$} \\
\hline Dcohort 1930_39 & 0.016 & 0.01 & -0.027 & 0.014 & 0.026 & 0.024 & -0.002 & 0.001 & 0.026 \\
\hline & {$[0.01]$} & {$[0.01]$} & {$[0.01]^{* *}$} & {$[0.02]$} & {$[0.02]^{*}$} & {$[0.02]$} & {$[0.01]$} & {$[0.01]$} & {$[0.01]^{* *}$} \\
\hline Dcohort 1945_49 & 0.006 & 0.006 & 0.037 & -0.01 & -0.01 & -0.004 & 0.002 & 0.002 & -0.02 \\
\hline & {$[0.01]$} & {$[0.01]$} & {$[0.01]^{* * *}$} & {$[0.02]$} & {$[0.02]$} & {$[0.02]$} & {$[0.01]$} & {$[0.01]$} & {$[0.01]$} \\
\hline Dcohort 1950_59 & -0.022 & -0.016 & 0.049 & -0.047 & -0.052 & -0.045 & 0.026 & 0.022 & -0.026 \\
\hline & {$[0.01]$} & {$[0.01]$} & {$[0.01]^{* * *}$} & {$[0.02]^{* *}$} & {$[0.02]^{* *}$} & {$[0.02]^{* *}$} & {$[0.01]^{*}$} & {$[0.01]$} & {$[0.01]^{*}$} \\
\hline Dcohort 1960_69 & -0.017 & -0.014 & 0.093 & -0.109 & -0.103 & -0.097 & 0.032 & 0.031 & -0.045 \\
\hline & {$[0.02]$} & {$[0.02]$} & {$[0.02]^{* * *}$} & {$[0.03]^{* * *}$} & {$[0.03]^{* * *}$} & {$[0.03]^{* * *}$} & {$[0.02]$} & {$[0.02]$} & {$[0.02]^{* *}$} \\
\hline Dcohort 1970_74 & 0.08 & 0.07 & 0.229 & -0.212 & -0.182 & -0.161 & -0.068 & -0.062 & -0.175 \\
\hline & {$[0.03]^{* * *}$} & {$[0.03]^{* * *}$} & {$[0.02]^{* * *}$} & {$[0.04]^{* * *}$} & {$[0.04]^{* * *}$} & {$[0.04]^{* * *}$} & {$[0.03]^{* *}$} & {$[0.03]^{* *}$} & {$[0.03]^{* * *}$} \\
\hline Dcohort 1975_84 & 0.308 & 0.293 & 0.517 & -0.366 & -0.336 & -0.293 & -0.29 & -0.277 & -0.437 \\
\hline & {$[0.03]^{* * *}$} & {$[0.03]^{* * *}$} & {$[0.03]^{* * *}$} & {$[0.06]^{* * *}$} & {$[0.06]^{* * *}$} & {$[0.06]^{* * *}$} & {$[0.04]^{* * *}$} & {$[0.04]^{* * *}$} & {$[0.04]^{* * *}$} \\
\hline Year Dummies & & & & & & & & & \\
\hline Dyear 1988 & -0.097 & -0.085 & & -0.014 & 0.005 & & 0.116 & 0.096 & \\
\hline & {$[0.02]^{* * *}$} & {$[0.02]^{* * *}$} & & {$[0.02]$} & {$[0.02]$} & & {$[0.02]^{* * *}$} & {$[0.02]^{* * *}$} & \\
\hline Dyear 1990 & -0.101 & -0.074 & & -0.004 & -0.073 & & 0.111 & 0.103 & \\
\hline & {$[0.02]^{* * *}$} & {$[0.02]^{* * *}$} & & {$[0.02]$} & {$[0.02]^{* * *}$} & & {$[0.02]^{* * *}$} & {$[0.02]^{* * *}$} & \\
\hline Dyear 1992 & -0.115 & -0.087 & & -0.027 & -0.104 & & 0.127 & 0.121 & \\
\hline & {$[0.01]^{* * *}$} & {$[0.01]^{* * *}$} & & {$[0.02]$} & {$[0.02]^{* * *}$} & & {$[0.01]^{* * *}$} & {$[0.01]^{* * *}$} & \\
\hline Dyear 1994 & -0.084 & -0.06 & & -0.048 & -0.124 & & 0.068 & 0.065 & \\
\hline & {$[0.01]^{* * *}$} & {$[0.01]^{* * *}$} & & {$[0.02]^{* *}$} & {$[0.02]^{* * *}$} & & {$[0.01]^{* * *}$} & {$[0.01]^{* * *}$} & \\
\hline Dyear 1996 & -0.239 & -0.221 & & -0.058 & -0.123 & & 0.183 & 0.184 & \\
\hline & {$[0.01]^{* * *}$} & {$[0.01]^{* * *}$} & & {$[0.02]^{* * *}$} & {$[0.02]^{* * *}$} & & {$[0.01]^{* * *}$} & {$[0.01]^{* * *}$} & \\
\hline Dyear 1998 & -0.275 & -0.265 & & -0.028 & -0.069 & & & & \\
\hline & {$[0.01]^{* * *}$} & {$[0.01]^{* * *}$} & & {$[0.02]$} & {$[0.02]^{* * *}$} & & & & \\
\hline Dyear 2000 & -0.222 & -0.206 & & -0.039 & -0.099 & & 0.287 & 0.287 & \\
\hline & {$[0.01]^{* * *}$} & {$[0.01]^{* * *}$} & & {$[0.02]^{* *}$} & {$[0.02]^{* * *}$} & & {$[0.01]^{* * *}$} & {$[0.01]^{* * *}$} & \\
\hline Dyear 2002 & -0.082 & -0.083 & & -0.041 & -0.042 & & 0.114 & 0.115 & \\
\hline & {$[0.01]^{* * *}$} & {$[0.01]^{* * *}$} & & {$[0.01]^{* * *}$} & {$[0.01]^{* * *}$} & & {$[0.01]^{* * *}$} & {$[0.01]^{* * *}$} & \\
\hline City Size Dummies & & & & & & & & & \\
\hline Dcity1 (Tokyo) & & -0.058 & -0.066 & & 0.169 & 0.168 & & -0.014 & -0.008 \\
\hline & & {$[0.01]^{* * *}$} & {$[0.01]^{* * *}$} & & {$[0.02]^{* * *}$} & {$[0.02]^{* * *}$} & & {$[0.01]$} & {$[0.01]$} \\
\hline Dcity2 (Government-Decreed Cities) & & -0.073 & -0.073 & & 0.155 & 0.155 & & 0.001 & 0.002 \\
\hline & & {$[0.01]^{* * *}$} & {$[0.01]^{* * *}$} & & {$[0.01]^{* * *}$} & {$[0.01]^{* * *}$} & & {$[0.01]$} & {$[0.01]$} \\
\hline Dcity3 (City with population greater & & -0.048 & -0.047 & & 0.13 & 0.131 & & -0.011 & -0.01 \\
\hline or equal to 150,000 ) & & {$[0.01]^{* * *}$} & {$[0.01]^{* * *}$} & & {$[0.01]^{* * *}$} & {$[0.01]^{* * *}$} & & {$[0.01]$} & {$[0.01]$} \\
\hline Dcity4 (City with population greater & & -0.035 & -0.035 & & 0.1 & 0.101 & & -0.002 & -0.002 \\
\hline or equal to 50,000 ) & & {$[0.01]^{* * *}$} & {$[0.01]^{* * *}$} & & {$[0.01]^{* * *}$} & {$[0.01]^{* * *}$} & & {$[0.01]$} & {$[0.01]$} \\
\hline Dcity5 (City with population less & & -0.027 & -0.03 & & -0.007 & -0.008 & & 0.03 & 0.031 \\
\hline than 50,000$)$ & & {$[0.01]^{* *}$} & {$[0.01]^{* *}$} & & {$[0.02]$} & {$[0.02]$} & & {$[0.01]^{* *}$} & {$[0.01]^{* *}$} \\
\hline Higher Education Dummy & & & & & & & & & \\
\hline Duniversity degree & & -0.043 & -0.097 & & 0.208 & 0.165 & & -0.034 & 0.021 \\
\hline & & {$[0.01]^{* * *}$} & {$[0.01]^{* * *}$} & & {$[0.01]^{* * *}$} & {$[0.01]^{* * *}$} & & {$[0.01]^{* * *}$} & {$[0.01]^{* *}$} \\
\hline Income & & 0.000 & 0.000 & & 0.000 & 0.000 & & 0.000 & 0.000 \\
\hline & & {$[0.00]^{* * *}$} & {$[0.00]^{* * *}$} & & {$[0.00]^{* * *}$} & {$[0.00]^{* * *}$} & & [0.00] & {$[0.00]$} \\
\hline Household Size & & -0.021 & -0.026 & & -0.003 & -0.005 & & 0.027 & 0.032 \\
\hline & & {$[0.00]^{* * *}$} & {$[0.00]^{* * *}$} & & {$[0.00]$} & {$[0.00]^{*}$} & & {$[0.00]^{* * *}$} & {$[0.00]^{* * *}$} \\
\hline Market Conditions & & & & & & & & & \\
\hline Real Interest Rate of Deopits & & & 0.023 & & & -0.028 & & & 0.078 \\
\hline & & & {$[0.01]^{* * *}$} & & & {$[0.01]^{* *}$} & & & {$[0.01]^{* * *}$} \\
\hline Return Difference between Stocks & & & -0.036 & & & -0.006 & & & 0.05 \\
\hline and Deposits (rs - rd) & & & {$[0.01]^{* * *}$} & & & {$[0.01]$} & & & {$[0.01]^{* * *}$} \\
\hline Volatility of Stocks & & & -0.004 & & & -0.002 & & & 0.006 \\
\hline & & & {$[0.00]^{* * *}$} & & & {$[0.00]$} & & & {$[0.00]^{* * *}$} \\
\hline Constant & 0.797 & 0.917 & 0.913 & -0.333 & -0.48 & -0.49 & -0.009 & -0.086 & -0.169 \\
\hline & {$[0.01]^{* * *}$} & {$[0.01]^{* * *}$} & {$[0.03]^{* * *}$} & {$[0.02]^{* * *}$} & {$[0.02]^{* * *}$} & {$[0.04]^{* * *}$} & {$[0.01]$} & {$[0.02]^{* * *}$} & {$[0.03]^{* * *}$} \\
\hline Observations & 24,593 & 24,593 & 24,539 & 24,593 & 24,593 & 24,539 & 22,375 & 22,375 & 22,325 \\
\hline Uncensored Observations & 18,812 & 18,812 & 18,772 & 4,597 & 4,597 & 4,589 & 13,371 & 13,371 & 13,344 \\
\hline Log likelihood & $-15,275.83$ & $-15,106.05$ & $-15,428.20$ & $-9,881.89$ & $-9,348.61$ & $-9,357.48$ & $-14,387.97$ & $-14,287.10$ & $-14,558.26$ \\
\hline
\end{tabular}




\section{APPENDiX II: Key CREDit SUPPORT MEASURES In RESPONSE TO THE FinANCIAL CRISIS AND THE EARTHQUAKE}

44. Temporary SME Financing Facilitation. The SME Financing Facilitation Act was put in place effective from December 2009 through March 2013 (extended twice). It encourages financial institutions to accommodate request by SMEs to ease credit terms on existing loans and to provide consulting services to SMEs in smoothing credits. The FSA's revision of inspection manual and supervisory guidelines has relaxed the requirement of classifying restructured loans as 'normal'.

45. Credit guarantees programs. At nearly 8 percent of GDP, Japan's credit guarantee system is sizeable and widespread. Nearly 40 percent of SMEs use guarantees (about $¥ 35$ trillion in total). On top of normal credit guarantees, emergency and counter-cyclical credit guarantees cover 100 percent of SME debt liability has been available for SMEs of almost any industry.

\begin{tabular}{lll}
\hline & \multicolumn{1}{c}{$\begin{array}{c}\text { Standard Credit } \\
\text { Guarantees }\end{array}$} & \multicolumn{1}{c}{$\begin{array}{c}\text { Special and Emergency Credit } \\
\text { Guarantees }\end{array}$} \\
\hline Guarantee limit & $\begin{array}{ll}¥ 280 \text { million } \\
\text { of which : unsecured loans } \\
¥ 80 \text { million. }\end{array}$ & \\
& 80 percent of loans under & \\
Guarantee percentage & $\begin{array}{l}\text { accountability-sharing } \\
\text { system }\end{array}$ & 100 percent \\
Guarantee fees & 1.15 percent on average & about 0.8-1.0 percent on average \\
\hline Source: SME Agency, METI.
\end{tabular}

46. Safety-net financing. Eligible SMEs could pay reduced interest rates on loans, provided by the SME Agency and various GFIs, with budget amount up to ¥15.4 trillion, twice extended to expire by March 2013. The government also injected about $¥ 310$ billion into regional financial institutions to bolster their capital positions and facilitate their intermediary functions.

47. Employment Adjustment Subsidy program. This short-term work scheme covered at its peak nearly 3.8 percent of the labor force, the largest coverage amongst industrialized countries. Main recipients were firms in the manufacturing sector and SMEs, accounting for about 80 percent of subsidy in FY2008-09. Eligibility was eased after the earthquake (Steinberg, 2011). 


\section{APPENDIX III: REFORMS OF JAPAN POST BANK AND INSURANCE AND OTHER GFIS}

\section{Since the last FSAP, reforms have taken place in several GFIs.}

- Japan Housing Finance Agency (JHF) was established to replace the former GHLC. The main business of the JHF shifts towards purchasing mortgage loans from private institutions through securitization support business. It also provides some interest rate support on housing loans.

- Other selected GFIs. Initial steps of most GFI reforms took place in October 2008. JFC was established as a result of the merger of four policy-based (GFIs). ${ }^{15}$ The JFC primarily finances safety-net lending and reinsures credit guarantees provided by 52 local CGCs. Shoko Chukin Bank (SCB) became a joint-stock company pursuant to the Shoko-Chukin Bank Act, with full privatization within a roughly five- to seven-years time frame. The Development Bank of Japan (DBJ) also became a stock company with shares held by the government. ${ }^{16}$

- Fiscal Investment Loan Program. The FILP has undertaken a fundamental reform in FY2001, including (i) eliminating mandatory deposits of postal savings and pension reserves to the Trust Fund bureau such that the FILP funding is entirely raised from market issuances; (ii) higher scrutiny on FILP-agency projects to improve efficiency and transparency of FILP agencies management and bond issuance without government guarantees; (iii) improve disclosures on financial conditions. Since then, the outstanding amount and new issuance of FILP debt have both declined except rising after the global financial crisis and the Great East Japan Earthquake. In general, the procurement costs of interest payment on FILP-agency bonds are higher than those on central government. Since the FILP reform, the deposit savings and pension reserves have been invested in the FILP bonds, while they have mainly been invested in government bonds.

\section{Since the last FSAP in 2003, privatization plans were put in place for Japan Post} with an ultimate aim to fully privatize the banking and insurance segments under the Japan Post. Japan Post Bank and Japan Post Insurance were incorporated in October 2007 based on the Japan Post Holdings Law and Postal Privatization Law of 2005, where government ownership was established through a holding company (Japan Post Holdings). Under this framework, the government was obligated to hold shares of Japan Post Holdings only up to more than one third permanently and to decrease the proportion of shareholding as early as possible. Under the amendment of the Postal Privatization Law in May 2012, Japan

\footnotetext{
${ }^{15}$ The four institutions include the National Life Finance Corporation (NLFC), the Agriculture, Forestry and Fisheries Finance Corporation (AFC), the Japan Finance Corporation for Small and Medium Enterprise (JASME) and the International Financial Operations (IFOs) of the Japan Bank for International Cooperation (JBIC).

${ }^{16}$ The Development Bank of Japan receives a government support on the financial base through capital injections up to end of Mar 2012, which was further extended to March 2015 after the earthquake.
} 
Post Holdings would aim to dispose its full shareholding of Japan Post Bank and Insurance as early as possible while taking consideration of their business conditions and the influence in ensuring basic postal services.

\section{Nevertheless, business plans of Japan Post Bank and Insurance are changing} gradually. Japan Post Bank is slowly diversifying its asset structure away from JGBs into corporate and foreign bonds. It is also seeking to offer new products, such as mortgages, although this would require the FSA's and Ministry of Internal Affairs and Communications (MIAC)'s approval and further investments in its risk management systems, as it moves towards nontraditional businesses. In the face of shrinking demand on traditional life products, the Japan Post Insurance intends to expand into the growing healthcare and medical products, upon the approval of the relevant ministries with hearing opinions from Postal Service Privatization Committee (PSPC) in addition to the approval of the Insurance Business Law. The approval process requires opinions from PSPC, and followed by approvals from the MIAC and the FSA. The statutory limitation to the scope of business is imposed on JPB and JPI, including the ceiling on the amount of deposits acceptable from a depositor for Japan Post Bank and on the amount of insurance payout for JPI.

\section{JPB and JPI are under the supervision of the FSA since 2007. The FSA has} established a specific office (Office for Postal Savings and Insurance Supervision) following the establishment of Japan Post Bank and Insurance under the Supervisory Bureau. Under the Banking Act and Insurance Business Act, the Japan Post Bank and Insurance each operates as a bank and insurance company. The office also conducts supervision on the Japan Post Holdings - a financial holding company controlling these companies. The supervision of JPB and JPI is conducted in a similar manner to the supervision of other private financial institutions. Specifically, the FSA ensures the financial soundness of JPB and JPI including their risk management and appropriate governance including compliance with laws and regulations.

\section{Since the inception in $\mathbf{2 0 0 7}$, the JPB and JPI have received no government} guarantees on deposits and policies. The deposits and policies are protected by the deposit insurance system under the DICJ (up to $¥ 10$ million) and life insurance policy holder protection system in the same way as other private banks and life insurance companies. As such, the JPB has been paying insurance premiums to the DICJ and the Japan Post Insurance has been paying the contributions to the Life Insurance Policy Holder Protection Corporation. JPB and JPI are also subject to corporate tax as are other private financial institutions. The FSA also conducts occasional inspection to the JPB and JPI. 


\section{APPENDIX IV. SME RESTRUCTURING}

\section{Accelerating SME restructuring is an integral part to revitalize SMEs to} promote long-term growth. SME restructuring has been a long standing structural issue in the previous Article IV Consultation Staff Reports. Following the enactment of the Civil Rehabilitation Act in 2000, Japan has made efforts to improve corporate restructuring through reforms of insolvency laws (Appendix Table 2 and Appendix Figure 1). ${ }^{17}$ Despite the frequent applications of the business rehabilitation procedures (7,100 applications made from the Act inception to end-FY2009), only 40 percent of SMEs achieved rehabilitation. ${ }^{18}$ Institutional features and lack of incentives help explain the lack of restructuring progress among SMEs. Specifically,

- From the SMEs' point of views, they have little incentive to seek restructuring due to high costs and bankruptcy risks, as they are cushioned with various measures to secure funding at a low cost. Multiple creditors and wide use of personal guarantees among SMEs in general also add difficulties in voluntary workouts or business transfers. Bankruptcy carries a high stigma and is considered a very costly event that prohibits another fresh start afterwards.

- From creditors' point of view, the size of loans is usually small for banks to initiate restructuring on a case-by-case basis. Second, recognizing the losses or unwinding the loan reclassification schemes could push up credit costs that have profit and capital implications. Third, generous credit guarantees programs (wide coverage, long maturity with possibilities of roll-over) have supported existing SMEs regardless of viability.

\section{Structural weaknesses among SMEs would require restructuring that allows an orderly exit of nonviable firms. Policy efforts could include:}

- $\quad$ Reducing leverage and improving incentives for corporate restructuring will help create space for new investment. In cases of out-of-court voluntary workouts, wider use of equity components (e.g. debt-equity swap or debt-debt swaps, of which subordinate debt could serve as capital to reduce borrowing costs) would incentivize banks and SMEs to undertake restructuring as banks capture the upside while the SMEs leverage is reduced. Policies could facilitate expedite restructuring process

\footnotetext{
${ }^{17}$ The SME Revitalization Support Councils and the Business Rehabilitation Alternative Dispute Resolution System (ADR) were established. The Corporate Reorganization Act and the Bankruptcy Act were amended to facilitate restructuring. The Industrial Revitalization Corporation of Japan (IRCJ) operated during 2003-2007 to dispose nonperforming loans and revitalize firms with excessive debts. Private equity and consulting firms also specialize in restructuring of distressed companies.

${ }^{18}$ Those SMEs that file under the Act has, on average, poorer financial conditions in terms of profitability and capital structure, and have sold off a higher proportion of assets, experiencing a greater decline in asset value three years prior to filing.
} 
through voluntary workouts and wider use of pre-packs (Laryea, 2010).

Considerations could also be given towards establishing an asset management company (AMC) tailored to SMEs to jumpstart restructuring-purchasing distress loans from banks or CGCs at discounted values such that financial institutions are less burdened by distress loans while SMEs could resume long-term investment following restructuring. Revision of credit guarantee program could complement SME restructuring, such as linking the eligibility of guarantees to progress of restructuring.

- Wider use of debtor-in-possession protection could help mitigate an erosion of firm value when the bankruptcy case is under review. Debtor-in-procession is a temporary funding means that allows an SME in bankruptcy to continue operations (during the period between the application request under the Civil Rehabilitation Act) and mitigates erosion of firm value in the process. Such protections often result in less moral hazard of managers in rent-seeking.

- $\quad$ Encourage more flexibility in the release of personal guarantees in restructuring. Around 80 percent of SMEs that have applied for civil rehabilitation have debts with personal-guarantees that exceed their personal assets. Even the SME loans are restructured, the relief does not usually extend to personally guaranteed debt.

- $\quad$ Reducing stigma of bankruptcies could help give failing entrepreneurs a chance to restart new businesses.

Appendix Table 2. Japan: Definition of SME Stipulated in the SME Basic Act

\begin{tabular}{|c|c|c|c|}
\hline \multirow[b]{2}{*}{ Industry } & \multicolumn{2}{|c|}{$\begin{array}{l}\text { Small and Medium-sized } \\
\text { Enterprises }\end{array}$} & \multirow{2}{*}{$\begin{array}{c}\text { of which: small } \\
\text { enterprises } \\
\text { Regular } \\
\text { employees }\end{array}$} \\
\hline & Capital & $\begin{array}{c}\text { Regular } \\
\text { employees }\end{array}$ & \\
\hline $\begin{array}{l}\text { Manufacturing, construction, } \\
\text { transport, and other industries }\end{array}$ & up to $¥ 300$ million & up to 300 & up to 20 \\
\hline 2 Wholesale & up to $¥ 100$ million & up to 100 & up to 5 \\
\hline 3 Retail & up to $¥ 50$ million & up to 50 & up to 5 \\
\hline 4 Services & up to $¥ 50$ million & up to 100 & up to 5 \\
\hline
\end{tabular}

Source: SME Agency, METI. 
Appendix Figure 1. Japan: SME Restructuring and Civil Rehabilitation Act

SME Applications under the Civil Rrehabilitation Act (In number)

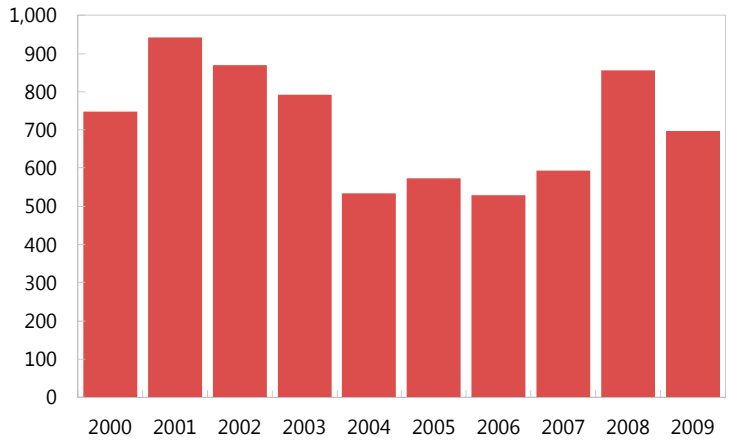

Source: Japan Small Business Research Institute

Areas of Concerns on Rehabilitation Support (in percent of responses)

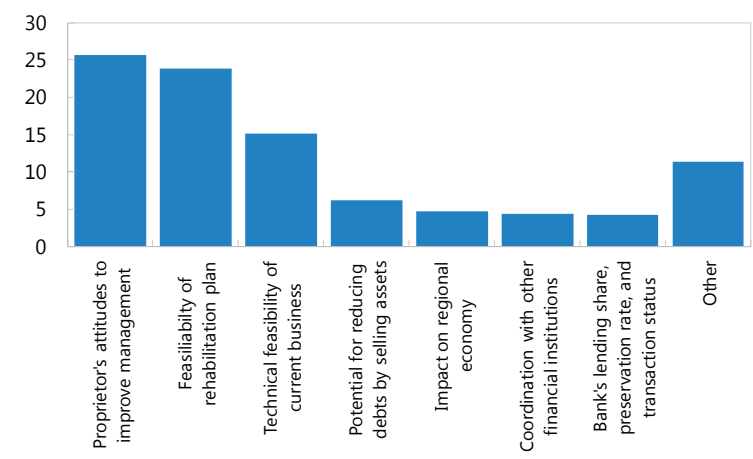

Source: Japan Small Business Research Institute

Obstacles to Continuation of Rehabilitation Support (in percent of multiple responses; after commencement)

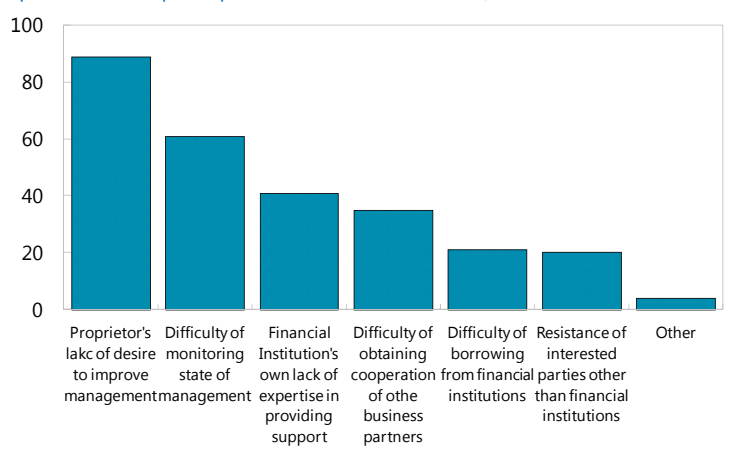

Source: Japan Small Business Research Institute

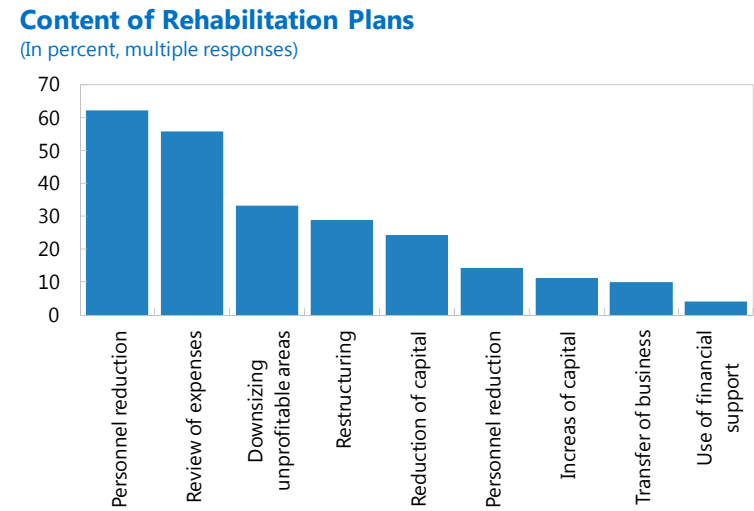

Source: Japan Small Business Research Institute

Debt Relief under Rehabilitation Plans (in percent of response)
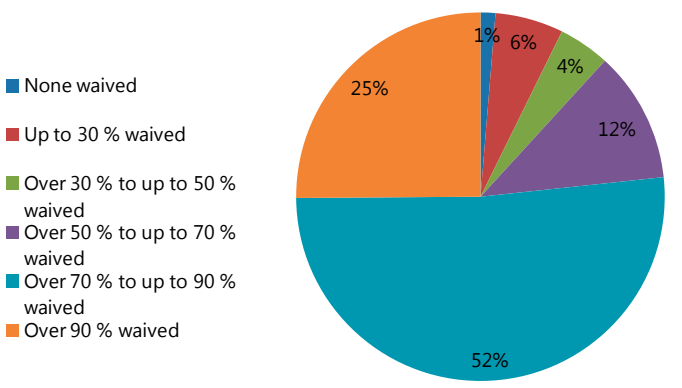

Source: Japan Small Business Research Institute

\section{Outcomes of Civil Rehabilitation}

(In percent of multiple responses)

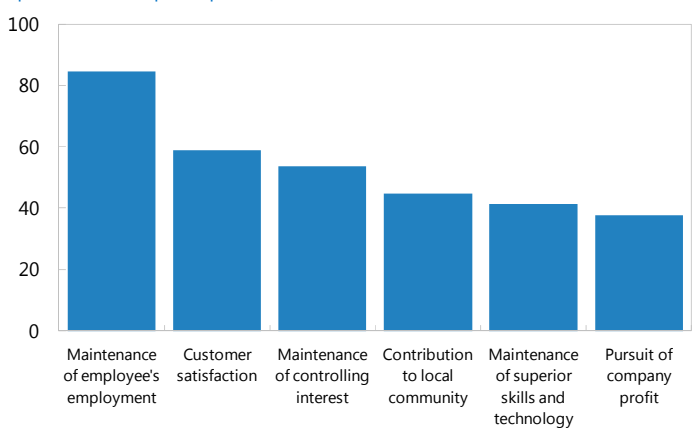

Source: Japan Small Business Research Institute 